\title{
EFEITOS DA ADIÇÃO DE BENZOATO DE SÓDIO NA FERMENTAÇÃO ALCOÓlICA PARA PRODUÇÃo DE AGUARDENTE DE CANA-DE-AÇÚCAR (Saccharum spp)
}

\section{RUDIMAR ANTONIO CHERUBIN}

Engenheiro Agrônomo

\author{
Orientador: Prof. Dr. LUIZ EDUARDO GUTIERREZ
}

Dissertação apresentada à Escola Superior de Agricultura "Luiz de Queiroz", Universidade de São Paulo, para a obtenção do título de Mestre em Ciências, Área de Concentração: Ciência e Tecnologia de Alimentos.

PIRACICABA

Estado de São Paulo - Brasil

Dezembro - 1998 
Dados Internacionais de Catalogação na Publicação (CIP) DIVISÃo DE BIBLIOTECA E DOCUMENTAÇÃo - Campus "Luiz de Queiroz"/USP

Cherubin, Rudimar Antonio

Efeitos da adição de benzoato de sódio na fermentação alcoólica para produção de aguardente de cana-de-açúcar (Saccharum spp.) / Rudimar Antonio Cherubin. Piracicaba, 1998.

$70 \mathrm{p}$.

Dissertaçăo (mestrado) - Escola Superior de Agricultura Luiz de Queiroz, 1998. Bibliografia.

1. Aguardente de cana-de-açúcar 2. Bebida alcoólica 3. Benzoato de sódio 4. Fermentaçāo alcoolica 5. Levedura I. Titulo

CDD 663.53 
Aos meus pais, Avelino e Zulma, dedico

À Ana Paula, ofereço. 


\section{AGRADECIMENTOS}

Expresso a minha profunda gratidão às pessoas e instituições que contribuíram para a concretização deste trabalho, em especial:

- Ao Prof. Dr. Luiz Eduardo Gutierrez, pela orientação, apoio, amizade e exemplo profissional e humano.

- Ao Prof. Dr. Jorge Horii, pelos ensinamentos e por gentilmente ceder os equipamentos

e as dependências do laboratório os quais foram indispensáveis à realização desta dissertação.

- Ao Prof. Dr. Gilvan Wosiacki, Da Universidade Estadual de Ponta Grossa, pelo incentivo e apoio permanente.

- Aos Profs. Dr. Fernando Valadares Novaes e Dr. Antonio Joaquim de Oliveira, pela constante atenção e valiosas sugestões.

- Aos funcionários do Departamento de Ciência e Tecnologia Agroindustrial da Escola Superior de Agricultura "Luiz de Queiroz" - USP- Ana Flora, Beatriz Giongo, Carlota dos Anjos, Constant Christofoletti, Eduardo Arthuso, Gislaine Oliveira, Luiz Rodrigues, Midiam Gustinelli, Noel Gonçalves, Pedro Filho, Pedro Lucentini, Regina Loureiro, Rosemary Mandro, Rubens Pereira, Sylvino Torrezan e Wilson Januário.

- A Regina Helena Gonçalves, pela dedicação na realização das análises 
cromatográficas das amostras.

- Aos funcionários do Laboratório de Tecnologia de Alimentos da Universidade Estadual de Ponta Grossa e do Departamento de Ciência e Tecnologia Agroindustrial da Escola Superior de Agricultura "Luiz de Queiroz" pelo auxílio na análise sensorial.

- Aos amigos Carlos Alberto França Ribeiro, Éder Giglioti e Lucia Rebellato pela amizade a apoio dedicados.

- À CAPES pelo auxílio financeiro concedido. 


\section{SUMÁRIO}

Página

LISTA DE APÊNDICES............................................................................. viii

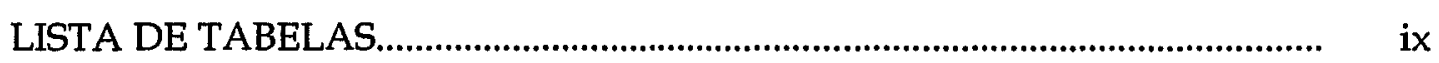

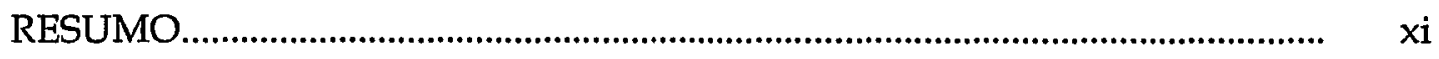

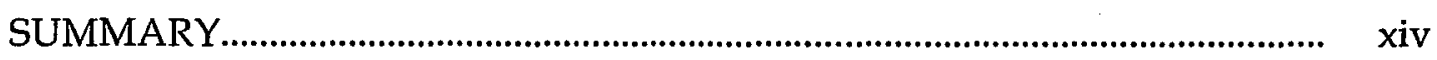

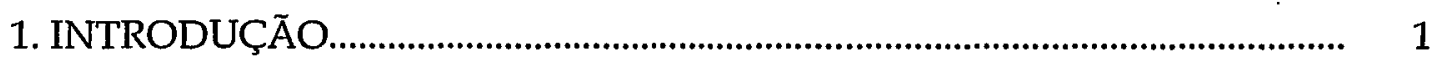

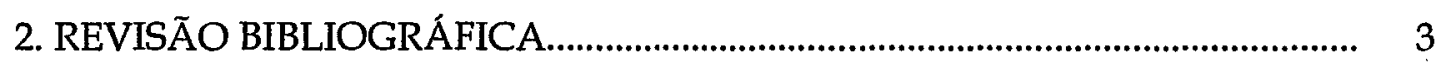

2.1 Produção e consumo de aguardentes.................................................................... 3

2.2 Compostos Voláteis....................................................................................... 7

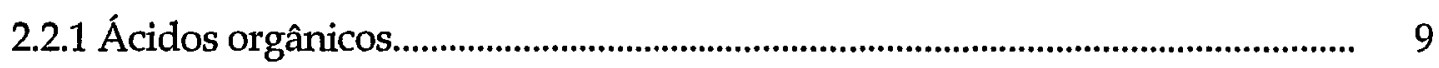

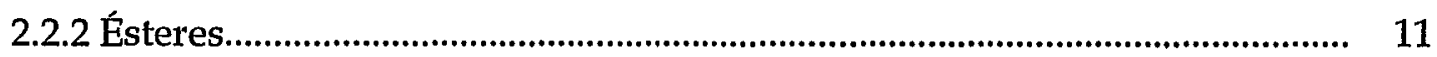

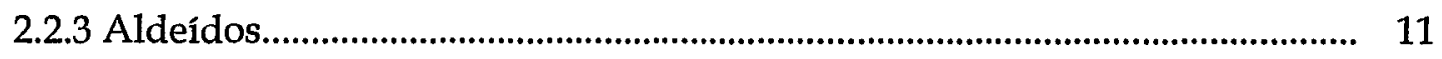

2.2.4 Furfural e hidroximetil-furfural................................................................ 12

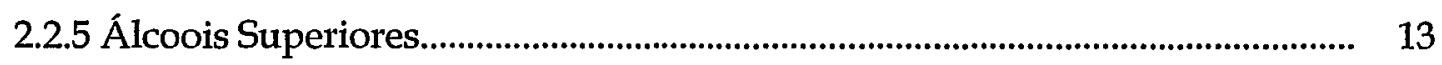

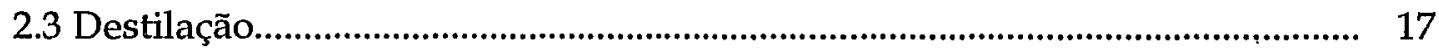

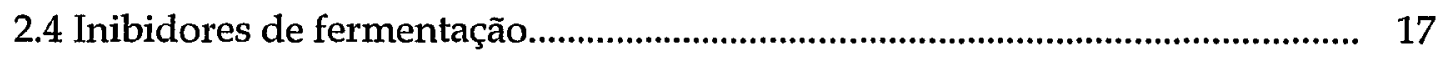

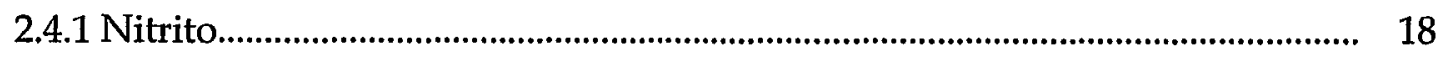

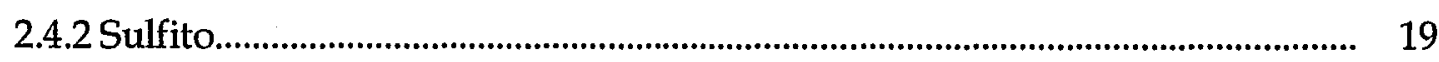

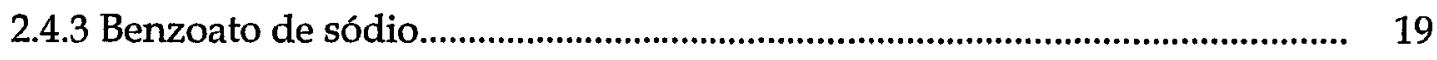

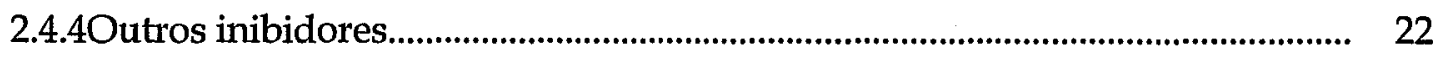

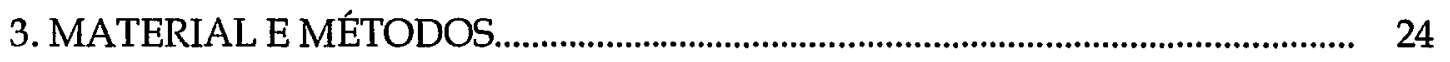

3.1 Matéria-prima para fermentação................................................................................. 24

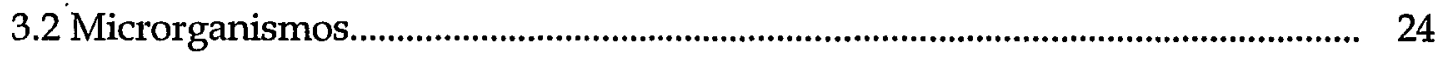

3.3 Meio de cultura para manutenção................................................................ 25 
3.4 Propagação dos microrganismos..................................................................... 25

3.4.1 Fase iniçial de propagação dos microrganismos............................................. 25

3.4.2 Fase final de propagação dos microrganismos............................................... 26

3.5 Tratamentos.................................................................................................... 27

3.6 Condução da fermentação................................................................................... 27

3.7 Produção de aguardente.......................................................................................... 28

3.8 Aparelho de destilação......................................................................................... 29

3.9 Solução estoque de benzoato de sódio..................................................................... 29

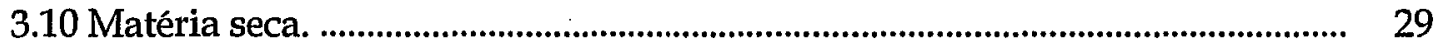

3.11 Acompanhamento da fermentação...................................................................... 30

3.12 Acidez volátil do vinho................................................................................. $\quad 30$

3.13 Número de células e viabilidade celular.................................................................. 30

3.14 Açúcares totais e residuais....................................................................................... 31

3.15 Acidez total............................................................................................................ 31

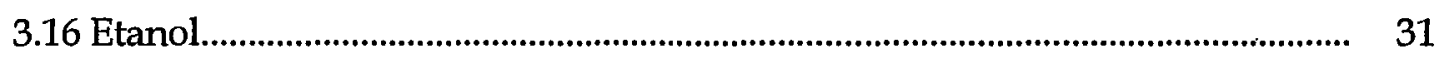

3.17 Compostos voláteis............................................................................................... 32

3.18 Análise estatística..................................................................................................... 32

3.19 Análise sensorial............................................................................................ 32

4. RESULTADOS E DISCUSSÃO......................................................................

4.1 Análise das amostras dos vinhos ................................................................... 34

4.1.1 Acidez total e volátil........................................................................................

4.1.2 Contagem total e viabilidade celular.............................................................. 36

4.1.3 Consumo de açúcares................................................................................ 38

4.1.4 Etanol e eficiência fermentativa........................................................................ 40

4.1.5 Tempo de fermentação..................................................................................... 42

4.1.6 Álcoois superiores........................................................................................... 43

4.2 Análises das amostras de aguardentes................................................................ 46

4.3 Análises sensoriais das aguardentes.............................................................. 48

4.4 Considerações.................................................................................................. 50

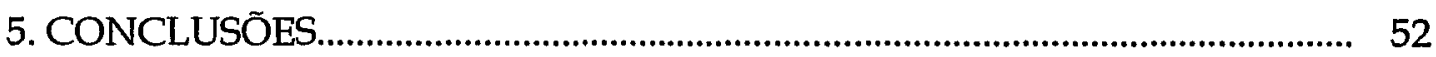




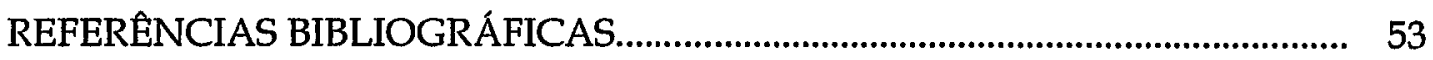

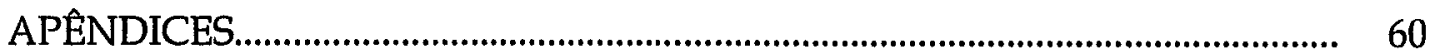




\section{LISTA DE APÊNDICES}

Página

1 Vias biossintéticas de formação de álcoois superiores (Webb \& Ingraham, 1963)

2 Modelo de ficha utilizado para a analise sensorial (teste triangular) de aguardente (Dutcosky, 1996).

3 Modelo de ficha utilizado para a análise sensorial (teste triangular) de aguardente (Dutcosky, 1996).

4 Teores de ácidos orgânicos nos vinhos, em g.L-1, expressos em ácido acético, médias de quatro repetições.

5 Teores de ácidos voláteis nos vinhos, em g.L-1-1, expressos em ácido acético, médias de quatro repetições.

6 Número total de células (células. $\mathrm{mL}^{-1}$ ) e viabilidade celular (\%) das leveduras após as fermentações, médias de quatro repetições........................ 65

7 Teores de açúcares residuais nos vinhos, em g.L-1 expressos em glucose, médias de quatro repetições.

8 Teor alcoólico dos vinhos, em g.L-1, médias de quatro repetições.

9 Efeito da adição de benzoato de sódio no tempo de fermentação, em horas, médias de quatro repetições.

10 Teores de álcool n-propílico nos vinhos, em mg.100 $\mathrm{mL}^{-1}$, médias de quatro repetições..

11 Teores de álcool isoamílico nos vinhos, em mg.100 $\mathrm{mL}^{-1}$, médias de quatro repetições.

12 Teores de álcool isobutílico nos vinhos, em $\mathrm{mg} .100 \mathrm{~mL}^{-1}$, médias de quatro repetições. 


\section{LISTA DE TABELAS}

Página

1 Consumo de algumas bebidas alcoólicas no Brasil, em 1987, em caixas de nove litros.

2 Evolução da produção e do consumo per capita de aguardente no Brasil (1970 a 1985)

3 Padrões de identidade e qualidade para a aguardente de cana, em g.100 $\mathrm{mL}^{-1}$ de álcool anidro (a.a.)

4 Álcoois superiores produzidos por leveduras em fermentações realizadas em três temperaturas e em meio sintético com $14 \%$ de sacarose, em mg.L.1....

5 Produção de álcoois superiores pela IZ-1904 em meio sintético com quatro concentrações de sacarose, à temperatura de $35^{\circ} \mathrm{C}$.

6 Concentrações mínimas e máximas de álcoois em 185 amostras de aguardentes de cana de várias origens, em $\mathrm{mg} \cdot 100 \mathrm{~mL}^{-1}$ de álcool anidro.

7 Utilização de açúcares (\%) por Sacchnromyces rouxi var. polymorphus em diferentes concentrações de benzoato de sódio (mg. $\left.\mathrm{L}^{-1}\right)$, em diferentes $\mathrm{pH} . \quad 21$

8 Efeitos da adição de benzoato de sódio na formação de ácidos orgânicos, em g.L-1 ${ }^{-1}$ expressos em ácido acético, médias de quatro repetições................

9 Efeitos da adição de benzoato de sódio na formação de ácidos voláteis, em g.L-1 , expressos em ácido acético, médias de quatro repetições.

10 Efeitos da adição de benzoato de sódio sobre o número total de células (células.mL-1) e viabilidade celular (\%), médias de quatro repetições...........

11 Açúcares residuais, em g. $\mathrm{L}^{-1}$ expressos em glucose, médias de quatro repetições. 
12 Teor alcoólico dos vinhos após fermentações realizadas com 0, 100 e 150mg. $\mathrm{L}^{-1}$ de benzoato de sódio, em g. $\mathrm{L}^{-1}$, médias de quatro repetições........

13 Eficiência de fermentação, com base no rendimento proveniente da equação de Gay-Lussac (51,1g de etanol.100g de glicose-1), médias de

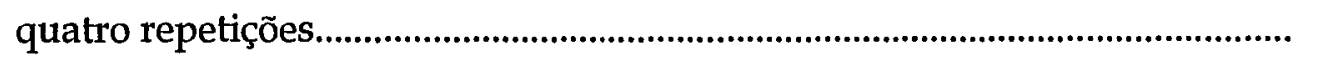

14 Efeitos da adição de benzoato de sódio no tempo de fermentação, em horas, médias de quatro repetições................................................................

15 Teores de álcool n-propílico nos vinhos, em $\mathrm{mg} \cdot 100 \mathrm{~mL}^{-1}$, médias de quatro repetições.

16 Concentrações do álcool isoamílico nos vinhos, em $\mathrm{mg} .100 \mathrm{~mL}^{-1}$, médias de quatro repetições.

17 Concentrações de álcool isobutílico nos vinhos, em $\mathrm{mg} .100 \mathrm{~mL}^{-1}$, médias de quatro repetições.

18 Análise cromatográfica das aguardentes produzidas em alambique, em mg.100 $\mathrm{mL}^{-1}$ de álcool anidro, médias de duas repetições.

19 Análise sensorial de sabor de aguardentes, realizada por equipe não selecionada de provadores com escala hedônica de nove pontos.

20 Análise sensorial de aroma de aguardentes, realizada por equipe não selecionada de provadores, com escala hedônica de nove pontos..................

21 Resultados da análise sensorial, teste triangular, das aguardentes realizada por equipe selecionada de provadores. 


\title{
EFEITOS DA ADIÇÃO DE BENZOATO DE SÓDIO NA FERMENTAÇÃO ALCOÓLICA PARA PRODUÇÃO DE AGUARDENTE DE CANA-DE-AÇÚCAR
} (Saccharum spp)

\author{
Autor: RUDIMAR ANTONIO CHERUBIN \\ Orientador: Prof. Dr. LUIZ EDUARDO GUTIERREZ
}

\section{RESUMO}

Muitos inibidores podem ser adicionados ao meio de fermentação com a finalidade de alterar o metabolismo da levedura e assim possibilitar alterações em características como a redução de produção de células e de componentes indesejáveis ou a melhoria do rendimento fermentativo. Entre os inibidores metabólicos já testados o benzoato de sódio é um dos mais promissores pois reduz a produção do principal componente do óleo fúsel, o álcool isoamílico; entretanto, o sal foi testado apenas na fermentação de melaço e não na de caldo de cana. Neste trabalho foi estudado o efeito da adição de sal nas concentrações de 100 e 150 $\mathrm{mg}^{\mathrm{L}} \mathrm{L}^{-1} \mathrm{em}$ mosto de caldo de cana-de-açúcar diluído até $150 \mathrm{~g} \cdot \mathrm{L}^{-1}$ de açúcares redutores totais e inoculado com a levedura Saccharomyces cerevisiae linhagem IZ-1904 na proporção de $14,0 \mathrm{~g} \cdot \mathrm{L}^{-1}$ de matéria seca, em condições laboratoriais, à temperatura de $32,0 \pm 1,0^{\circ} \mathrm{C}$. Após o término da fermentação os vinhos foram centrifugados, as células foram reutilizadas como inóculo para a fermentação seguinte e o vinho delevurado foi analisado. A metodologia foi repetida até o final do quarto ciclo fermentativo, quando foi encerrado o ensaio. $O$ tratamento com o inibidor propiciou uma redução significativa do teor alcoólico, do consumo de açúcares, da viabilidade celular, do número de células. $\mathrm{mL}^{-1}$, dos álcoois isoamílico e isobutílico, e reduziu entre 30,30 e $51,49 \%$ a formação de álcoois superiores. Por sua vez, o teor de 
álcool n-propílico não foi alterado significativamente, e a acidez volátil, a acidez total e o tempo de fermentação tiveram um aumento significativo. Em seguida, foram produzidas aguardentes com e sem o sal inibidor, as quais foram submetidas as análises sensoriais de preferência, realizado por equipe de 64 provadores não selecionados e não treinados, e de diferença, por equipe de oito provadores selecionados, e não foram detectadas diferenças organolépticas entre as bebidas. Os resultados obtidos indicam que adições contínuas de benzoato de sódio na fermentação alcoólica reduzem a formação de álcoois superiores sem alterar as características sensoriais da aguardente, porém, causam redução da atividade fermentativa da levedura. Portanto, para a sua recomendação na produção de aguardente de cana são necessárias mais informações, pois muitos de seus efeitos na fermentação ainda precisam ser estudados e sugere-se a continuidade dos estudos sobre o uso do sal em outras linhagens de leveduras e aliado a alguma técnica de inibição do desenvolvimento bacteriano. 


\title{
EFFECT OF BENZOATE SODIUM ON SUGAR CANE JUICE (Saccharum spp) FERMENTATION FOR BRANDY PRODUCTION
}

\author{
Author: RUDIMAR ANTONIO CHERUBIN \\ Adviser: Prof. Dr. LUIZ EDUARDO GUTIERREZ
}

\section{SUMMARY}

Many inhibitors can be added to the fermentation media in order to alter the yeast metabolism and, consequently, to make possible alterations in some characteristics as a reduction in the production of cell mass and in the formation of undesirable components or an increase in the fermentation. It is known that among the metabolic inhibitors the sodium benzoate is one of the most promising since it decreases the production of the main component of the fusel oil, the isoamylic alcohol; however, the effects of the salt on fermentation was determined only for molasse. It was studied the effect of benzoate sodium on sugar cane juice fermentation by Saccharomyces cerevisiae lineage IZ-1904. The inhibitor salt was added at the beginning of the fermentation at 100 and $150 \mathrm{mg} \cdot \mathrm{L}^{-1}$ of juice diluted to $150 \mathrm{~g} \cdot \mathrm{L}^{-1}$ total reducing sugars. Fermentation was performed by $14,0 \mathrm{~g}$ of dry yeast cells per litter of juice. After the process, the yeast cells were centrifuged and reused in four fermentative cycles. Treatments with benzoate resulted in a significant decrease on the ethanol productivity, alcohol rate, sugars consume, cellular viability, cells number per milliliter, and isoamylic and isobutylic alcohol. The reduction in the amount of high alcohol proportioned by the addition of the salt varied from 30.30 to $51.49 \%$. The volatile and total acids rate and fermentation time were significantly increased. The amount of npropylic alcohol was not altered. No significant differences between spirit produced 
with and without the inhibitor salt was detected by analyzing its sensorial characteristics of preference and of difference performed by 64 and eight evaluators, respectively. Although the sprit quality was not affected, a lower fermentative activity by the yeast was detected when benzoate sodium was added continuously. So, since the benzoate sodium is known as a reductor of higher alcohol contents, its recommendation for this purpose, mainly in sugarcane brandy production needs more information because some undesirable effects on fermentation could be expected. 


\section{INTRODUÇÃO}

A aguardente de cana-de-açúcar é uma bebida alcoólica bastante popular entre os brasileiros, é produzida em todo o Território Nacional e está sendo considerada, em muitos casos, a bebida característica do País, assim como o uísque para a Escócia e a tequila para o México.

Por causa da elevada variação na composição das aguardentes, foi necessário que a Legislação Nacional estabelecesse determinados limites para alguns componentes, principalmente para aqueles considerados tóxicos e que integram a fração não-álcool dos destilados como: acidez, ésteres, aldeídos, furfural, cobre e álcoois superiores. Foram determinados padrões de identidade e qualidade para aguardentes obtidas a partir de diferentes matérias-primas e os específicos para aquelas produzidas a partir de cana-de-açúcar.

A fermentação alcoólica é a fase na qual são produzidos os principais componentes químicos da aguardente, inclusive os álcoois superiores, sendo que muitos dos quais podem influir no aroma e no sabor da bebida.

De qualquer forma, a presença de álcoois superiores nas aguardentes, em concentrações acima do limite aceito pela legislação fato verificado principalmente nas aguardentes artesanais é indesejável e torna evidente a necessidade de pesquisas visando sua redução de maneira econômica devido ao baixo valor que a bebida normalmente é comercializada.

A redução dos álcoois superiores na bebida pode ser realizada de duas maneiras. Um método é usando determinadas colunas de destilação que realizam a separação dos álcoois superiores durante a destilação; entretanto, o equipamento é de custo elevado para os produtores de aguardentes artesanais. 
Outra medida que pode ser utilizada é o uso de inibidores metabólicos que promovem a redução da produção de álcoois superiores durante a fermentação com um menor custo operacional, além de ser uma tecnologia de fácil repasse aos produtores. Esta metodologia é adequada principalmente para pequenos produtores, para os quais a produção de aguardentes é tida apenas como fonte de renda adicional no processo de diversificação do sistema de agroindustrialização.

Dos muitos inibidores pesquisados o mais promissor é o benzoato de sódio, pois possibilita a redução dos álcoois n-propílico, isobutílico e isoamílico, quando utilizado na fermentação alcoólica de melaço (Gutierrez et al., 1991).

O álcool isoamílico é o álcool superior em maior concentração no óleo fúsel, representa mais de $50 \%$ do total, e o benzoato de sódio promove a sua redução na produção, conseqüência da menor formação de acetil-coenzima-A. Com a menor disponibilidade da coenzima ocorre redução na síntese do ácido alfacetoisocapróico, um precursor da leucina, diminui a formação de leucina e de álcool isoamílico. Outras características interessantes do inibidor são a sua alta solubilidade, o baixo custo, o fácil manuseio, além de não ser corrosivo.

Dada a potencialidade do benzoato de sódio, é interessante verificar o seu efeito na fermentação de caldo de cana-de-açúcar em condições semelhantes àquelas utilizadas por grande parte dos pequenos produtores de aguardentes artesanais, bem como a viabilidade técnica de seu uso.

$O$ objetivo do presente trabalho foi verificar o efeito da adição de benzoato de sódio sobre a fermentação e avaliar parâmetros de acidez total, acidez volátil, açúcares residuais, teor alcoólico, tempo de fermentação, eficiência fermentativa, concentração celular (células. $\mathrm{mL}^{-1}$ ), viabilidade celular e álcool álcoois superiores dos vinhos e comparar a qualidade organoléptica das bebidas obtidas na presença do inibidor em relação àquelas obtidas na sua ausência. 


\section{REVISÃO BIBLIOGRÁFICA}

A aguardente de cana, também conhecida como "caninha" ou "cachaça", é uma bebida tipicamente brasileira que foi inicialmente produzida e consumida por escravos, mas posteriormente tornou-se um produto característico do meio rural e de pequenas cidades do interior. Atualmente está disponível em requintados bares e restaurantes de todo o País e até mesmo no exterior (Chaves \& Póvoa, 1992).

De acordo com a legislação brasileira, Portaria $n^{\circ} 371$ do Ministério da Agricultura e reforma Agrária (Brasil, 1974), a aguardente de cana é uma bebida com graduação alcoólica entre $38^{\circ}$ e $54^{\circ} \mathrm{GL}$, obtida de destilado alcoólico simples de cana-deaçúcar (Saccharum spp) ou pela destilação de mosto fermentado de cana, sendo facultativa a adição de água, aç car, caramelo ou o seu envelhecimento. É considerada envelhecida aquela que contiver um mínimo de $20 \%$ de destilado alcoólico simples envelhecido de cana, sendo permitida a correção de cor pela adição de caramelo. Caso a aguardente contenha mais de $60 \mathrm{~g}$ de aç car. $\mathrm{L}^{-1}$, deve ter acrescida à sua denominação a expressão "adoçada".

Apesar do hábito, é inadequado denominar a aguardente de "cachaça", já que diferem pela matéria-prima utilizada; pois, pela definição legal, a "cachaça" é somente obtida pela destilação de mosto fermentado de melaço, resultante da produção de aç car.

\subsection{Produção e consumo de aguardentes}

A aguardente de cana é a bebida alcoólica destilada mais consumida no País e a segunda entre todas as alcoólicas, perdendo apenas para a cerveja. O consumo 
é ainda maior quando são consideradas as bebidas elaboradas a partir de aguardente, como os conhaques populares, e outras bebidas nas quais a aguardente participa da composição, fato verificado em aguardentes compostas, caipirinhas, batidas de frutas e "blends" de uísques nacionais. Comparativamente, as demais bebidas alcoólicas apresentam consumo muito menor, cujos valores estão apresentados na Tabela 1.

Tabela 1. Consumo de algumas bebidas alcoólicas no Brasil, em 1987, em caixas de nove litros.

\begin{tabular}{lr}
\hline bebida & \multicolumn{1}{c}{ caixas } \\
\hline aguardente & 100.000 .000 \\
vinho de mesa & 3.000 .000 \\
vodka & 2.500 .000 \\
conhaque & 2.500 .000 \\
uísque nacional & 2.000 .000 \\
vermutes & 2.000 .000 \\
aperitivos & 1.000 .000 \\
rum & 1.000 .000 \\
uísque & 300.000 \\
champanhe espumante & 300.000 \\
licores & 300.000 \\
gim & 250.000 \\
\hline
\end{tabular}

Fonte: Chaves \& Póvoa (1992).

Os dados e estimativas referentes à produção e ao consumo de aguardentes são muito contraditórios, pois a sua comercialização no mercado chamado "informal" não é incorporada as avaliações estatísticas. Parte desta produção é realizada por pequenos produtores que fabricam até 1000 litros diários de produto sem marca registrada. Para estes produtores a atividade é apenas uma fonte de renda adicional no processo de diversificação do sistema de agroindustrialização.

Portanto, tanto os dados de produção quanto os de consumo de 
aguardentes são, em geral, estimativas de pessoas envolvidas no setor e indicam uma produção anual entre 1,2 e 2,0 bilhões de litros. Alguns arriscam valores superiores a dois bilhões, dos quais cerca de $95 \%$ são provenientes de destilarias de médio e grande porte (Novaes, 1996).

De qualquer forma, o consumo anual per capita de aguardente é elevado e estima-se que seja aproximadamente 8,72 litros (Tabela 2). Segundo Coelho (1990) ocorre uma elevação de consumo no período compreendido entre 18 e 21 horas, quando são ingeridas diariamente 60 milhões de doses de aguardente.

A carência de dados estatísticos sobre o setor produtivo de aguardente dificulta uma pesquisa mais aprofundada sobre o assunto, forçando o estudo com dados estimados por pesquisadores, produtores e comerciantes. Muitas estimativas indicam que aproximadamente 5.000 propriedades rurais produzem cana-de-açúcar e colhem 8.500.000 toneladas, destinadas exclusivamente para a produção de aguardentes; sendo o Estado de São Paulo responsável pela metade da produção nacional de aguardente. Possivelmente a produção envolve em torno de 10.000 trabalhadores rurais, movimentando anualmente cerca de três bilhões de dólares .

A definição de aguardente de qualidade é uma tarefa difícil devido a fatores como a ausência de padrões de qualidade e as preferências regionais para determinados atributos de sabor e aroma.

Cabe ressaltar que a preferência do mercado consumidor por aguardentes de baixo valor comercial facilita a adoção de práticas que propiciam aumentos na produtividade ou redução de custos e dificulta a adoção daquelas que tornam o processo mais oneroso. Entretanto, este fato está sendo gradualmente modificado e atualmente existe uma parcela do mercado, mais exigente, suficiente para gerar a demanda por aguardentes de qualidade.

A matéria-prima para a fabricação da aguardente é a cana-de-açúcar, que é cultivada praticamente em todo o País. Salientar a importância que a cultura representa é redundante, seja na produção de açúcar para consumo humano, de álcool carburante para veículos ou na fabricação bebidas alcoólicas. 
Tabela 2. Evolução da produção e do consumo per capita de aguardente no Brasil (1970 a 1985).

\begin{tabular}{lccc}
\hline ano & $\begin{array}{c}\text { população brasileira } \\
\text { (1000 habitantes) }\end{array}$ & $\begin{array}{c}\text { produção } \\
(1000 \text { litros) }\end{array}$ & $\begin{array}{c}\text { consumo per capita } \\
\text { (litros) }\end{array}$ \\
\hline 1970 & 94.509 & 418.113 & 4,42 \\
1971 & 95.993 & 464.482 & 4,83 \\
1972 & 98.690 & 515.992 & 5,22 \\
1973 & 111.433 & 573.217 & 5,64 \\
1974 & 104.243 & 636.832 & 6,10 \\
1975 & 107.145 & 669.084 & 6,23 \\
1976 & 110.125 & 702.964 & 6,37 \\
1977 & 113.209 & 738.568 & 6,51 \\
1978 & 116.393 & 775.971 & 6,65 \\
1979 & 119.670 & 815.269 & 6,80 \\
1980 & 123.032 & 856.556 & 6,95 \\
1981 & 126.329 & 900.000 & $7,27^{*}$ \\
1982 & 129.715 & 964.980 & $7,61^{*}$ \\
1983 & 133.191 & 1.034 .652 & $7,96^{*}$ \\
1984 & 136.760 & 1.109 .353 & $8,33^{*}$ \\
1985 & 140.426 & 1.189 .449 & $8,72^{*}$ \\
\hline
\end{tabular}

Fonte: Aguardente em Minas Gerais', citado por Furtado (1995).

* estimativas.

Segundo Copersucar (1987), o caldo de cana é constituído de água (aproximadamente $82,0 \%$ ) e sólidos solúveis (aproximadamente 18,0\%). Os sólidos solúveis mais importantes são os açúcares e são representados principalmente pela sacarose, que apresenta um valor médio de $14,0 \%$, glucose, $0,4 \%$, e frutose, $0,2 \%$. Teores elevados de glucose e frutose demonstram um estágio pouco adiantado de maturação da cana. Outros compostos orgânicos são substâncias nitrogenadas (proteínas, aminoácidos), gorduras, ceras, pectinas, ácidos (málico, succínico, aconítico, entre

${ }^{1}$ AGUARDENTE EM MINAS GERAIS. Belo Horizonte, Instituto de Desenvolvimento Industrial, 1982, 89p. 
outros) e matérias corantes (clorofila, sacaretina e antocianina). As substâncias inorgânicas, representadas pela cinza, têm como componentes principais: sílica, potássio, fósforo, cálcio, sódio, magnésio, enxofre, ferro e alumínio.

A matéria-prima destinada à produção de aguardentes com boas características organolépticas deve ser de excelente qualidade, estar perfeitamente madura, apresentar boas condições fitossanitárias, sem indícios de deterioração, não passar pela queima no campo, possuir adequada concentração de açúcares fermentesciveis e, se possivel, não ter contato com o solo após o corte (Lima, 1992 e Novaes, 1997).

No Brasil toda a aguardente é produzida exclusivamente por via fermentativa, não sendo permitido pela legislação o uso de álcool obtido por via sintética. Os microrganismos mais utilizados no processo industrial de fermentação alcoólica são linhagens das leveduras Saccharomyces cerevisiae, Saccharomyces uvarum, Schizosaccharomyces pombe e Kluyveromyces sp (Gutierrez, 1989).

\subsection{Compostos Voláteis}

Segundo Gutierrez (1992), a fermentação alcoólica é a principal etapa do processo de produção de aguardente de cana pois é a fase na qual são produzidos os principais componentes químicos da bebida, pela ação direta ou indireta da levedura e de outros microrganismos atuantes nesta fase.

A proporção dos componentes no vinho pode ser influenciada não somente pela qualidade da matéria-prima, mas também pelas condições de assepsia nas operações de moagem e filtragem e, sobretudo, pela condução do processo de fermentação alcoólica (Lima, 1983). Outros fatores também podem exercer influência sobre a composição dos vinhos, tais como: concentração de açúcares; uso de inibidores de fermentação; de linhagens de leveduras e diferentes $\mathrm{pH}$ do meio de fermentação (Gutierrez, 1989; 1994).

Após a fermentação o mosto passa a ser chamado de vinho, sendo 
composto por água e álcool etílico, em maiores proporções, e muitos outros componentes que constituem a fração "não-álcool". Muitas vezes a fração "não-álcool", também chamada de impurezas voláteis, compostos voláteis ou então de componentes secundários, é formada por substâncias voláteis e confere às diferentes bebidas destiladas suas características peculiares de aroma e sabor.

Os principais componentes constituintes da fração "não-álcool" de aguardentes de cana são: aldeído acético, ácidos succínico, acético, láctico e ésteres desses ácidos, glicerol, furfural e álcoois superiores como: amílico, isoamílico, butílico, isobutílico, propílico e isopropílico (Lima, 1983).

Segundo Suomalainem (1971), os principais componentes responsáveis pelo aroma das bebidas são produzidos pelas leveduras durante a fermentação e a sua produção depende da espécie da levedura e das condições da fermentação. Entre os componentes aromáticos produzidos, os álcoois superiores desempenham papel importante, concomitantes com ésteres e ácidos.

O aroma das bebidas alcoólicas é formado por compostos voláteis e a maioria das bebidas destiladas possuem os mesmos componentes, porém, em quantidades diferentes e a diferenciação entre os aromas ocorre em função da variação da quantidade desses compostos (Suomalainem \& Lehtonen, 1978).

Por causa da aguardente ser uma complexa mistura de compostos oriundos da matéria-prima, além de outros produzidos durante a fermentação e alguns formados na destilação, tornou-se necessário que a Legislação Federal estabelecesse o teor da fração "não-álcool", fixando os valores máximos para alguns componentes que podem ser prejudiciais à saúde do consumidor. Esses teores foram denominados de padrões de identidade e qualidade.

Os padrões para a aguardente de cana estão apresentados na Tabela 3 e têm somente a finalidade de limitar a concentração e assim moderar a toxidez da bebida, não significando que aquela que se enquadrar nos padrões exigidos possa ser considerada um produto de qualidade organoléptica superior (Novaes, 1996). 
Tabela 3. Padrões de identidade e qualidade para a aguardente de cana, em g.100mL-1 de álcool anidro (a.a.).

\begin{tabular}{lcc}
\hline \multicolumn{1}{c}{ componente } & máximo & mínimo \\
\hline álcoois superiores & 0,300 & -- \\
álcool metílico & 0,200 & -- \\
ésteres & 0,250 & -- \\
acidez volátil & 0,150 & -- \\
aldeídos & 0,030 & -- \\
furfural & 0,005 & -- \\
cobre & 0,0005 & - \\
total não-álcool & 0,650 & 0,200 \\
\hline
\end{tabular}

Fonte: Brasil (1974).

Como as aguardentes são bebidas alcoólicas obtidas pela destilação de vinho, em que os compostos voláteis formados na fermentação são acrescidos àqueles formados durante a destilação, torna-se importante o conhecimento dos mecanismos de formação de alguns dos principais componentes bem como algumas de suas características que estão sucintamente descritas a seguir:

\subsection{1 Ácidos orgânicos}

O excesso de acidez é o problema mais comum observado em aguardentes e causa depreciação da qualidade da bebida devido ao sabor indesejável e ligeiramente "agressivo" apresentado pela bebida.

Os principais ácidos presentes em bebidas destiladas são: fórmico, acético, propiônico, butírico, capróico, cáprico, laúrico, mirístico e succínico. O acético é o predominante e sua concentração varia de 60 a $95 \%$ da acidez total (Nykanen \& Nykanen, 1991).

A produção do ácido acético ocorre pela contaminação do mosto por 
bactérias acéticas ou, em menores proporções, pelas leveduras, devido a ação da enzima desidrogenase de acetaldeído, que gera o ácido. A formação do ácido acético ocorre pela necessidade da levedura em gerar acetil-coenzima-A para a síntese de ácidos graxos, esteróides e aminoácidos, principalmente leucina. O referido ácido é produzido por meio de um desvio da síntese de etanol, desequilibrando o balanço de redox. Para cada mol de acetato ocorre a formação de duas enzimas reduzidas, gerando dois moles de glicerol (Gutierrez, 1994; 1997).

Apesar do ácido acético ser predominante, o principal ácido formado pela levedura é o succínico e pode ser obtido por duas vias: a redutiva e a oxidativa, sendo a última a prioritária em leveduras. Na via oxidativa, o piruvato é carboxilado até oxaloacetato, que por sua vez, condensa com acetil-coenzima-A até citrato, passando sucessivamente a isocitrato, alfa-cetoglutarato, succinil-coenzima-A e finalmente succinato (Alves, 1994).

A amplitude de teores de acidez em bebidas alcoólicas destiladas é consideravelmente elevada; no uísque escocês a literatura cita valores de $100 \mathrm{mg} \cdot \mathrm{L}^{-1}$ de álcool anidro; 200 para o conhaque e até 600 para o rum da Martinica (Suomalainen \& Lehtonen, 1978).

Fahrasmane (1983) analisou rum de diversas procedências e detectou que para o rum da Martinica, o ácido acético representa $76,4 \%$ da acidez volátil e o restante $(23,6 \%)$ é composto pelos ácidos: propiônico $3,35 \%$, isobutírico $6,74 \%$, butírico $4,41 \%$, isovalérico $4,0 \%$, valérico $0,24 \%$, capróico $3,21 \%$ e o 2 etil- 3 metil butírico $1,65 \%$.

As análises de acidez volátil de aguardentes de cana realizadas por Stupiello (1992) demostraram que a concentração máxima permitida pela legislação (150mg.100 $\mathrm{mL}^{-1}$ de álcool anidro) é bem superior àquelas verificadas na bebida. Em 185 aguardentes analisadas as concentrações variaram de 60,0 a $80,0 \mathrm{mg} \cdot 100 \mathrm{~mL}^{-1}$ de álcool anidro. 


\subsection{2 Ésteres}

O conjunto de ésteres é responsável, até mesmo quando presente em baixas concentrações, pelo buquê e por um aroma típico, agradável, pungente suave, que a aguardente adquire com o envelhecimento.

A maior parte dos ésteres presentes nas bebidas são formados pela atividade metabólica da levedura. A sua velocidade de formação aumenta quando a divisão celular cessa, porque a biossíntese de ésteres envolve a acetil-coenzima-A, produzida durante a fermentação pela ação da acetil-coenzima-A sintetase sobre o ácido acético e a acetil-coenzima-A. Com a interrupção da biossíntese de lipídeos, aumenta a disponibilidade de acetil-coenzima- $A$, aumentando a formação de ésteres (Quain, 1988).

Do total de ésteres presentes na aguardente de cana, o acetato de etila corresponde a cerca de $80 \%$ e confere odor e gosto ligeiramente desagradáveis. É formado durante a fermentação ou na destilação, como produto de esterificação entre álcool etílico e ácido acético, Hashizume², citado por Boza (1996).

Stupiello (1992) relatou que 88\% das 185 amostras de aguardentes analisadas continham entre 2,0 e $30,0 \mathrm{mg}$ de ésteres. $100 \mathrm{~mL}^{-1}$ de álcool anidro, ou seja, teores muito abaixo daquele permitido pela legislação vigente. Rosas et al. (1995) analisou brandy de laranja e divulgou valores médios entre 14,0 e 16,8mg de ésteres.100 $\mathrm{mL}^{-1}$ de álcool anidro.

\subsubsection{Aldeídos}

Outros componentes importantes encontrados em aguardentes são os aldeídos. Geralmente são formados durante a fermentação e são considerados produtos intermediários da rota biossintética de ácidos ou álcoois formados através da descarboxilação de alfa-cetoácidos pela ação da piruvato descarboxilase (Suomalainen

2 HASHIZUME, T. Considerações sobre ésteres nas bebidas alcoólicas. Instruções Técnicas, n.9, p.109-121, 1976. 
\& Lehtonem, 1978).

Normalmente os aldeídos não apresentam problemas em relação a legislação; conforme constatação de Stupiello (1992), no qual 71\% das aguardentes analisadas continham teores relativamente baixos, inferiores a $20,0 \mathrm{mg} .100 \mathrm{~mL}^{-1}$ de álcool anidro.

Nascimento et al. (1997) analisou aldeídos em 56 aguardentes e 10 uísques importados e concluiu que as aguardentes comerciais contêm menores concentrações de aldeídos que as artesanais e que, de modo geral, as aguardentes possuem menores teores que o uísque. $O$ teor médio de aldeídos nas aguardentes foi de $12,7 \mathrm{mg} .100 \mathrm{~mL}^{-1}$ de álcool anidro e nos uísques, $16,0 \mathrm{mg} .100 \mathrm{~mL}^{-1}$ de álcool anidro. $\mathrm{O}$ aldeído presente em maior concentração foi o acetaldeído.

Outro aldeído importante em bebidas destiladas é a acroleína (2propenal), formada pela desidratação do glicerol durante a destilação, a sua presença em aguardente é indesejável devido ao seu forte odor pungente (Gutierrez, 1997). Nascimento et al. (1997) relatou teores médios de acroleína na ordem de 0,067mg.100 $\mathrm{mL}^{-1}$ de álcool anidro em uísques importados, 0,094 em aguardentes comerciais e 0,364 em aguardentes artesanais.

\subsubsection{Furfural e hidroximetil-furfural}

O aquecimento do vinho durante a destilação promove a pirogenação da matéria orgânica presente no vinho, principalmente das hexoses e cetoses, gerando aldeídos furânicos como o furfural e o hidroximetil-furfural (Lehninger, 1990). A reação ocorre mais intensamente em $\mathrm{pH}$ ácido e temperatura elevada, como é o caso da destilação de vinhos obtidos pela fermentação do caldo de cana.

Apesar da elevada toxidez, o furfural e o hidroximetil-furfural geralmente não apresentam problemas por causa das reduzidas concentrações verificadas nas aguardentes.

Os valores médios de hidroximetil-furfural e furfural disponiveis na 
literatura são respectivamente 0,321 e $0,148 \mathrm{mg} \cdot 100 \mathrm{~mL}^{-1}$ de álcool anidro; nos uísques importados, 0,480 e 0,261mg. $100 \mathrm{~mL}^{-1}$ de álcool anidro nas aguardentes comerciais e 0,618 e 1,08mg.100 $\mathrm{mL}^{-1}$ de álcool anidro nas aguardentes artesanais (Nascimento et al., 1997).

\subsection{5 Álcoois Superiores}

Álcoois superiores são importantes componentes para a formação do aroma e sabor de bebidas alcoólicas e além disso dificultam a destilação dos vinhos. Entretanto, poucas pesquisas desenvolvidas com aguardentes deram ênfase à formação de álcoois superiores na fermentação alcoólica de caldo de cana.

Os álcoois superiores são produzidos por leveduras e bactérias, caracterizam-se pelo maior número de átomos de carbono e ponto de ebulição mais elevado que o álcool etílico.

Segundo Webb \& Inghaham (1963) e Almeida \& Barreto (1973), o óleo fúsel é obtido na fração de ponto de ebulição entre 90 e $150^{\circ} \mathrm{C}$ da destilação de um meio fermentado, sendo composto principalmente pelos álcoois: isoamílico ( 3 metil butanol-1), amílico opticamente ativo ( 2 metil butanol-1), que juntos correspondem a mais de $50 \%$ do total de óleo fúsel; isobutílico (2 metil propanol-1) e n-propílico. Suomalainen \& Nykanen (1966) complementam que a quantidade desses álcoois representa apenas 0,05 a 0,15\% do açúcar consumido pelas leveduras durante a fermentação alcoólica.

As leveduras são capazes de sintetizar todos os aminoácidos necessários para o seu crescimento e, de maneira geral, com o aumento do fornecimento de fonte nitrogenada, ocorre redução na produção de álcoois superiores (Ayrapaa, 1967 e Suomalainen \& Kahanpaa, 1963).

Webb \& Ingraham (1963) relatam que Ehrlich, em 1907, observou que os álcoois superiores são formados a partir dos aminoácidos, pois constatou que a adição de leucina durante a fermentação alcoólica estimulou a produção de álcool isoamílico. Contudo, o fornecimento de fonte de nitrogênio inorgânico inibiu a produção do óleo fúsel. No mesmo trabalho, também citam que em 1911, Neubauer e Fromherz estudaram 
o mecanismo de formação de álcoois superiores e propuseram que os aminoácidos são desaminados com produção de cetoácidos, os quais são descarboxilados e reduzidos, produzindo álcoois superiores em cadeia carbônica com um carbono a menos que o correspondente aminoácido de origem.

Atualmente, é aceitável que, a produção de álcoois superiores ocorra através da descarboxilação dos cetoácidos, reação catalisada pela enzima piruvato descarboxilase, intermediários na biossíntese dos aminoácidos valina, leucina e isoleucina, gerando aldeídos. Em seguida, os aldeídos produzidos bem como aqueles intermediários da biossíntese dos aminoácidos, são reduzidos pela ação da desidrogenase alcoólica, até álcoois, independentemente dos aminoácidos presentes no meio de fermentação, de acordo com o esquema apresentado no Apêndice 1 (Ayarapaa, 1967; Nordstrom, 1963; Suomalainen \& Kahanpaa, 1963; Suomalainen \& Keranen, 1967a e Yoshizawa et al., 1961).

A produção de álcoois superiores pode ser uma característica das linhagens das leveduras. Para esclarecer esse fato, Webb \& Kepner (1961) investigaram a formação de álcoois superiores por algumas linhagens de leveduras e relataram diferenças principalmente em relação aos teores de álcool n-propílico.

Hough \& Stevens (1961) sugeriram que o aumento na temperatura de fermentação promoveria maior formação de álcoois superiores. Rankine (1967) verificou que a elevação da temperatura de $15^{\circ} \mathrm{C}$ para $25^{\circ} \mathrm{C}$ causou aumento de $39 \%$ na produção do álcool isobutílico e de $24 \%$ no isoamílico e decréscimo de $17 \%$ no n-propílico.

Por sua vez, Gutierrez (1994) pesquisou diferenças entre as leveduras M300-A, IZ-1904, IZ-270 e Fleischmann quanto a produção de álcoois superiores por fermentação de meio sintético, mantidos em três temperaturas diferentes $(12,0$, 26,0 e $35,0^{\circ} \mathrm{C}$ ) e relatou que o álcool n-propílico não foi afetado significativamente pela variação de temperatura. Contudo, houve uma tendência de aumento na produção de álcoois superiores com o aumento da temperatura. Os resultados obtidos pelo pesquisador estão apresentados na Tabela 4.

Gutierrez (1994) sugere o uso das leveduras IZ-1904 e IZ-270 na produção de bebidas alcoólicas por causa da baixa produção de álcoois superiores apresentadas 
pelas mesmas durante os ensaios.

Tabela 4. Álcoois superiores produzidos por leveduras em fermentações realizadas em três temperaturas e em meio sintético com $14 \%$ de sacarose, em mg. $\mathrm{L}^{-1}$.

\begin{tabular}{ccccc}
\hline levedura & temperatura & \multicolumn{3}{c}{ álcoois superiores $\left(\mathrm{mg} . \mathrm{L}^{-1}\right)$} \\
\cline { 3 - 5 } & $\left({ }^{\circ} \mathrm{C}\right)$ & propílico & isobutílico & isoamílico \\
\hline \multirow{3}{*}{ M-300-A } & 12,0 & 8 & 57 & 203 \\
& 26,0 & 8 & 49 & 218 \\
& 35,0 & 8 & 55 & 247 \\
\hline \multirow{3}{*}{ Fleischmann } & 12,0 & 8 & 63 & 264 \\
& 26,0 & 9 & 64 & 292 \\
& 35,0 & 8 & 77 & 315 \\
\hline \multirow{2}{*}{ IZ-1904 } & 12,0 & 4 & 34 & 86 \\
& 26,0 & 4 & 33 & 132 \\
& 35,0 & 6 & 37 & 156 \\
\hline \multirow{2}{*}{ IZ-270 } & 12,0 & 8 & 50 & 227 \\
& 26,0 & 15 & 58 & 204 \\
\hline Fonte: Gutierrez (1994). & 15 & 36 & 141 \\
\hline
\end{tabular}

A Tabela 5 demonstra a variação na formação de álcoois superiores pela levedura Saccharomyces cerevisiae - IZ-1904, em diferentes concentrações de sacarose, observada por Gutierrez (1994).

Outros fatores como o $\mathrm{pH}$, o crescimento celular e a produção de etanol também podem influir; o aumento do $\mathrm{pH}$ do meio de fermentação promoveu aumento na taxa de multiplicação celular de leveduras e na formação de álcoois superiores (Rankine, 1967). Ayrapaa (1970) confirmou que a produção de álcoois superiores não só acompanhou o crescimento celular como também a formação de etanol. 
Tabela 5. Produção de álcoois superiores pela IZ-1904 em meios sintéticos com quatro concentrações de sacarose, à temperatura de $35^{\circ} \mathrm{C}$.

\begin{tabular}{cccc}
\hline sacarose & \multicolumn{3}{c}{ álcoois superiores $\left(\mathrm{mg}^{\mathrm{L}} \mathrm{L}^{-1}\right)$} \\
\cline { 2 - 4 }$(\%)$ & propílico & isobutílico & isoamílico \\
\hline 8,0 & 6 & 42 & 118 \\
11,0 & 6 & 37 & 142 \\
14,0 & 6 & 37 & 156 \\
16,0 & 5 & 42 & 168 \\
\hline
\end{tabular}

Fonte: Gutierrez (1994).

Em razão de tantas influências, ocorre grande variação nos teores de álcoois superiores nas aguardentes, mas de um modo geral os teores são elevados e frequientemente acima do permitido pela Legislação Nacional, fato que sugere a adoção de medidas que possibilitem a sua redução. A Tabela 6 demostra as concentrações de alguns álcoois verificados por Stupiello (1992), em 185 amostras de aguardentes.

Tabela 6. Concentrações mínimas e máximas de álcoois em 185 amostras de aguardentes de cana de várias origens, em mg.100 $\mathrm{mL}^{-1}$ de álcool anidro.

\begin{tabular}{lrr}
\hline \multicolumn{1}{c}{ componente } & mínimo & máximo \\
\hline etanol 1 & 33,43 & 66,92 \\
n-propílico & 2,60 & 77,00 \\
isobutílico & 4,41 & 24,00 \\
n-butílico & 0,44 & 7,14 \\
isoamílico & 5,43 & 671,00 \\
n-amílico & 0,00 & 0,95 \\
álcoois superiores & 2,60 & 825,00 \\
\hline
\end{tabular}

Fonte: Stupiello (1992).

${ }^{1}$ porcentagem (volume/volume). 


\subsection{Destilação}

Segundo Novaes et al. (1974) a destilação pode ser realizada de duas maneiras: destilação simples ou intermitente e a destilação contínua. Ambas têm a finalidade de extrair o álcool etílico contido no vinho, sob a forma de uma mistura hidroalcoólica, esgotando todas as possibilidades de exploração do vinho.

A destilação simples ou intermitente é realizada em aparelhos chamados de alambiques, sempre em pequenas produções (100 a 1000 litros.dia). Essas pequenas unidades apresentam uma produção "marginal", aproximadamente $5 \%$ da produção total, geralmente não possuem registro legal e o produto é comercializado regionalmente.

Durante a destilação, a temperatura de ebulição é invariável para cada líquido e independentemente da fonte de calor a temperatura permanecerá constante, desde que a pressão permaneça constante. Entretanto, a temperatura de ebulição de uma mistura de líquidos com diferentes pontos de ebulição depende da miscibilidade dos seus componentes e da pressão atuante. Em uma mistura de líquidos com diferentes pontos de ebulição, a temperatura de ebulição é intermediária àquelas dos componentes puros isoladamente e dependente da proporção de cada componente presente na mistura (Novaes et al., 1974).

É interessante ressaltar que ocorre, de modo similar, a formação de azeotrópicos na destilação de aguardentes, dificultando a eliminação ou a separação dos álcoois superiores durante o processo em aparelhos descontínuos (Boza, 1996). Contudo, a separação dos álcoois superiores durante a destilação é possível através do uso de colunas de destilação projetadas para este fim, entretanto, são processos onerosos e consequentemente não são utilizados por pequenos produtores.

\subsection{Inibidores de fermentação}

O uso de inibidores de desenvolvimento de microrganismos em alimentos 
é uma prática bastante corriqueira, com essa finalidade, muitos compostos já foram testados na tecnologia de produção de sucos e vinhos e alguns são amplamente usados caso do sulfito e do sorbato de potássio

A utilização de inibidores na produção de aguardentes serve para inibir totalmente a fermentação, mas apenas provocar alterações no metabolismo da levedura e dessa forma, favorecer a produção de algum composto desejável ou necessário e reduzir aqueles indesejáveis ou tóxicos. Alguns inibidores de fermentação foram testados e seus efeitos são conhecidos, caso do nitrito, do sulfito e do benzoato de sódio, entre outros (Gutierrez, 1989).

\subsubsection{Nitrito}

A ação do nitrito deve-se ao seu efeito na formação de alfa-hidroxietil pirofosfato de tiamina, que reduz a concentração de tiamina, a formação dos aminoácidos isoleucina, leucina e valina e a biossíntese dos álcoois isobutílico, isoamílico e amílico ativo. Entretanto, o uso do sal promove acúmulo de ácido alfa-cetobutírico e, portanto, não afeta a formação do álcool n-propílico. Outra ação do inibidor é a redução no conteúdo de ATP pela menor atividade da desidrogenase do gliceraldeído-3-fosfato e da descarboxilase pirúvica (Gutierrez \& De Martin, 1991)

Gutierrez \& De Martin (1991) estudaram a fermentação alcoólica com a adição de nitrito (em concentrações de 5, 10, 20, 40, 60 e 80mg.L-1) em meio sintético contendo $13,0 \%$ de sacarose com $\mathrm{pH} 4,0$ e concluíram que o aumento da concentração de nitrito promoveu aumento no tempo da fermentação, no acúmulo de trealose e glicogênio, mas não afetou a produção de etanol. O uso de $80 \mathrm{mg} \cdot \mathrm{L}^{-1}$ de nitrito reduziu a viabilidade celular de $83,2 \%$ para $73,0 \%$ e o teor de álcool isobutílico de 78,5 para $63,2 \mathrm{mg} . \mathrm{L}^{-1}$; no entanto, promoveu o aumento nos teores dos álcoois n-propílico (de 34,2 para $46,2 \mathrm{mg} \cdot \mathrm{L}^{-1}$ ) e isoamílico (de 15,0 para $76,0 \mathrm{mg} \cdot \mathrm{L}^{-1}$ ). 


\subsubsection{Sulfito}

A adição de sulfito causa elevação nos teores de aldeídos pois o sulfito complexa o acetaldeído, impedindo a regeneração da coenzima NAD. Também ocorre a redução na formação de álcoois superiores devido a destruição de um cofator, o pirofostato de tiamina e da enzima descarboxilase pirúvica porque esta é responsável pela descarboxilação do ácido pirúvico (Gutierrez, 1991; Suomalainem \& Oura, 1957 e 1958).

Segundo Gutierrez (1988a), a adição de sulfito em quatro concentrações $\left(19,69,119\right.$ e $\left.219 \mathrm{mg}^{-\mathrm{L}^{-1}}\right)$ ao mosto de melaço de cana com $\mathrm{pH} 4,0$ propiciou uma redução significativa nos teores dos álcoois n-propílico $\left(34,50 ; 23,25 ; 22,00 ; 19,75 \mathrm{mg}^{-L^{-1}}\right.$, respectivamente), isobutílico $\left(55,50 ; 48,50 ; 40,00 ; 37,25 \mathrm{mg} . \mathrm{L}^{-1}\right)$ e isoamílico $(129,00$; 124,75; 105,50; 99,00mg. $\left.\mathrm{L}^{-1}\right)$ do vinho; promoveu aumento no teor de acetaldeído e não foram detectadas diferenças significativas em relação aos teores de etanol. $O$ autor também observou que a elevação do $\mathrm{pH}$ do mosto sulfitado reduz o seu efeito na produção de álcoois superiores, porém aumenta a formação de acetaldeído devido a complexação.

Cherubin et al. (1995) pesquisou o efeito da adição de metabissulfito de sódio na produção de brandy de laranja e relatou que a adição de 0;20;50;100; 150 e 200mg. $\mathrm{L}^{-1}$ do inibidor resultou em bebidas destiladas com teores de 4,10;5,70;6,20;9,70; 15,50 e $21,40 \mathrm{mg}$ de aldeídos. $100 \mathrm{~mL}^{-1}$ de álcool anidro, estabelecendo um índice de correlação de 0,98 entre as concentrações de inibidor adicionado e a formação de aldeídos.

\subsubsection{Benzoato de sódio}

A ação inibitória e conservadora do ácido benzóico foi descrita pela primeira vez por H. Frenck, em 1875, quando pesquisava um substituto para o ácido salicílico. A sua utilização mais comum é na forma de benzoato de sódio que possui fórmula $\mathrm{C}_{6} \mathrm{H}_{5} \mathrm{COONa}$, peso molecular 141,1 , seu código de rotulagem no Brasil é P.I. e o 
internacional é E 211 (Almeida, 1995 e 1996).

O benzoato de sódio é considerado um ativo conservador principalmente contra leveduras e bactérias e também apresenta a vantagem de não ser corrosivo. O uso na forma de sais de cálcio, potássio e sódio é preferido por causa da elevada solubilidade apresentada; $50 \mathrm{~g}$ de benzoato de sódio dissolvem-se em $100 \mathrm{~mL}$ de água ou $1,3 \mathrm{~g}$ em $100 \mathrm{~mL}$ de álcool, à temperatura de $25^{\circ} \mathrm{C}$, enquanto que o ácido livre apresenta baixa solubilidade, $0,34 \mathrm{~g} .100 \mathrm{~mL}^{-1}$ de água. Felizmente, durante o uso o sal é convertido na forma ácida que corresponde à forma ativa de inibição. Outra característica importante em alimentos salgados é o efeito sinergístico existente entre o cloreto de sódio e o benzoato de sódio (Chichester, 1985).

A eficiência do inibidor é da ordem de 100 vezes maior em substratos ácidos que naqueles ligeiramente alcalinos e o $\mathrm{pH}$ ótimo para o efeito inibitório é entre 2,5 e 4,0. O pesquisador relata ainda que em $\mathrm{pH}$ entre 2,3 e 2,4 foram necessários 0,02 a 0,03\% de benzoato de sódio para inibir a fermentação de sucos de frutas inoculados com Saccharomyces ellipsoideus; enquanto que em pH 3,5 a 4,0 foram necessários 0,06 a 0,10\% (Chichester, 1985).

O referido inibidor também é mais eficiente em meios com baixos teores de aminoácidos e o ácido nicotínico interfere no processo de inibição (Simão, 1985). Pensando assim pode-se esperar que seja mais eficiente em caldo de cana do que em melaço, pois o caldo contém menores teores de aminoácidos que o melaço.

O benzoato de sódio é amplamente utilizado como aditivo de alimentos em muitos países, inclusive no Brasil, mas alguns países impõem restrições ao seu uso; como a França, que permite seu uso apenas em coalhadas e a Itália e Portugal que não permitem sua utilização em bebidas.

Simão (1985) relata que o Departamento de Agricultura dos Estados Unidos realizou pesquisas em relação ao consumo de alimentos com o inibidor e concluiu:

- A ingestão de benzoato de sódio em doses pequenas, de até $0,5 \mathrm{~g}$.dia, não é prejudicial à saúde e acima de 4 g.dia não tem efeito prejudicial à saúde, mas pode alterar ligeiramente determinados processos bioquímicos; 
- A adição de benzoato de sódio não altera o valor biológico dos alimentos;

- Não ocorre acúmulo no organismo porque o benzoato de sódio reage com a glicina formando ácido hipúrico, dessa forma são eliminados entre 66 e $95 \%$ do total ingerido e o restante é conjugado à ácido glucônico.

Norman (1970) pesquisou o efeito inibitório de 250, 500, 750 e $1000 \mathrm{mg} . \mathrm{L}^{-1}$ do benzoato de sódio em Saccharomyces rouxi var. polymorphus, em meio sintético e em diferentes $\mathrm{pH}$, e quantificou o consumo de açúcares, em porcentagem pelo microrganismo, em relação ao total de açúcares disponível. Os resultados obtidos estão apresentados na Tabela 7.

O uso de benzoato de sódio na fermentação alcoólica diminui a produção de acetil-coenzima-A, que é necessária para a síntese do ácido alfacetoisocapróico e consequentemente reduz a produção da leucina e do álcool isoamílico. Também reduz a formação de álcool n-propílico, provavelmente pela redução do ácido oxaloacético pela piruvato descarboxilase, portanto, reduz a produção de ácido aspártico, que é um dos precursores da treonina e do álcool n-propílico.

Tabela 7. Utilização de açúcares (\%) por Saccharomyces rouxi var. polymorphus em diferentes concentrações de benzoato de sódio $\left(\mathrm{mg}^{\mathrm{L}} \mathrm{L}^{-1}\right)$ e em diferentes $\mathrm{pH}$.

\begin{tabular}{ccccc}
\hline & \multicolumn{4}{c}{ benzoato de sódio $\left(\mathrm{mg} \cdot \mathrm{L}^{-1}\right)$} \\
\cline { 2 - 5 } $\mathrm{pH}$ & 250 & 500 & 750 & 1000 \\
\hline 6,0 & 21 & 23 & 15 & 13 \\
5,5 & 29 & 18 & 14 & 9 \\
5,0 & 26 & 19 & 1 & 5 \\
4,5 & 25 & 13 & 0 & 0 \\
4,0 & 12 & 13 & 0 & 0 \\
\hline
\end{tabular}

Fonte: Norman, 1970.

A adição de $150 \mathrm{mg} \cdot \mathrm{L}^{-1}$ de benzoato de sódio em mosto de melaço, corrigido para $15,0 \%$ de açúcares redutores totais e $\mathrm{pH} 4,0$, durante 2 ciclos fermentativos utilizando o reciclo de células, ocasionou uma redução significativa nos teores de álcoois 
isoamúlico (de 79,50 para 71,20mg. $\left.\mathrm{L}^{-1}\right)$ e n-propílico $\left(50,60\right.$ para $\left.36,80 \mathrm{mg} \cdot \mathrm{L}^{-1}\right)$ sem alterar a viabilidade celular (95\%) e a produção de etanol (7,80\%). O uso do inibidor durante 4 e 6 ciclos fermentativos ocasionou um aumento significativo de etanol, porém ocorreu redução nos teores de glicerol e dos álcoois n-propílico $\left(50,60\right.$ para 26,70 e $19,30 \mathrm{mg} . \mathrm{L}^{-1}$ respectivamente), isobutílico (54,30 para 47,30 e $\left.39,30 \mathrm{mg}^{-L^{-1}}\right)$ e isoamílico (79,50 para 61,20 e 52,70mg.L-1) (Gutierrez et al., 1991).

Devido aos resultados obtidos, Gutierrez et al. (1991), sugere a possibilidade do uso de benzoato em destilarias de álcool combustivel e a continuidade de estudos com o inibidor. Entretanto, há a necessidade de se estudar a adição do sal em condições mais próximas àquelas verificadas em pequenas unidades produtoras da bebida.

\subsubsection{Outros inibidores}

O uso dos ácidos fórmico e propiônico em concentrações de 250, 500 e $1000 \mathrm{mg} . \mathrm{L}^{-1}$ na fermentação alcoólica de mosto sintético com $125,0 \mathrm{~g} . \mathrm{L}^{-1}$ de sacarose e $\mathrm{pH}$ 4,0 não afetou significativamente a produção dos álcoois n-propílico, isobutílico e isoamílico e nem o rendimento fermentativo da levedura Saccharomyces cerevisiae (Gutierrez, 1988b).

Os álcoois etanol, n-butanol e isoamílico provocam decréscimo na viabilidade de células de Saccharomyces cerevisiae, agindo o n-butanol e isoamílico de maneira sinergística com o etanol; mas linhagens de Saccharomyces cerevisiae e Saccharomyces uvarum apresentam comportamento semelhante quanto à tolerância ao etanol (Okolo et al., 1987). Walsh \& Martin (1977) concluíram que o aumento da concentração de etanol diminui a taxa de crescimento e reduz a viabilidade celular.

A inibição do crescimento de leveduras causada pelo etanol, deve-se à redução da atividade de enzimas glicolíticas como a descarboxilase pirúvica, ocasionando aumento na excreção de ácido pirúvico e redução da formação de álcoois superiores (Gutierrez, 1991). 
Segundo Gao e Fleet (1988), a temperatura e o $\mathrm{pH}$ afetam o efeito tóxico do etanol sobre as leveduras pois verificaram que a $15,0^{\circ} \mathrm{C}$, a máxima concentração de etanol que permitiu o crescimento de Saccharomyces cerevisiae foi 15,0\%, e que a sensibilidade ao etanol aumentou com o decréscimo do $\mathrm{pH}$ de 6,0 para 3,0. De acordo com Walsh \& Martin (1977), para Saccharomyces cerevisiae, a temperatura ótima para crescimento foi de 30,0 a $35,0^{\circ} \mathrm{C}$ enquanto que para Sacharomyces uvarum essa temperatura foi de 26,8 a $30,4^{\circ} \mathrm{C}$.

O ácido acético afeta a absorção de fosfato e a atividade de enzimas glicoliticas e também reduz o $\mathrm{pH}$ intracelular. Gutierrez (1991) pesquisou o efeito da adição de 1050, 2100 e $4200 \mathrm{mg} \cdot \mathrm{L}^{-1}$ de ácido acético sobre a fermentação alcoólica e verificou redução dos álcoois n-propílico, isobutílico e isomílico, do crescimento celular, glicerol e aumento dos teores de etanol e açúcares residuais.

De acordo com Saigal \& Viswanathan (1983), a adição de óleos vegetais e ácidos graxos ao meio de fermentação promoveu aumento na produção de etanol e preveniu a inativação das leveduras em temperaturas elevadas; enquanto que Gutierrez et al. (1990) trabalhando com levedura Saccharomyces cerevisiae, obtida aerobicamente com adição dos ácidos graxos oléico e linoléico em meios com 14,0\% e 16,0\% de sacarose, não encontrou diferença na viabilidade celular. Entretanto, as leveduras obtidas anaerobicamente em meio enriquecido com ácido palmítico apresentaram redução na produção de álcoois superiores e na viabilidade celular. 


\section{MATERIAL E MÉTODOS}

Os ensaios foram realizados nos laboratórios do Setor de Açúcar e Álcool do Departamento de Ciência e Tecnologia Agroindustrial da Escola Superior de Agricultura "Luiz de Queiroz"- USP, em Piracicaba (SP).

\subsection{Matéria-prima para fermentação.}

Foi utilizada cana-de-açúcar cultivada na referida Instituição. Os colmos foram cortados sem a sua queima no campo, despalhados manualmente e submetidos a moagem, em um terno de moenda, sem embebição. Imediatamente após a moagem o caldo foi rapidamente resfriado até $5^{\circ} \mathrm{C}$, filtrado, congelado e armazenado a $-18^{\circ} \mathrm{C}$.

\subsection{Microrganismos.}

O microrganismo utilizado foi a levedura Saccharomyces cerevisiae (IZ1904), fornecida pelo Departamento de Ciência e Tecnologia Agroindustrial da Escola Superior de Agricultura "Luiz de Queiroz"- USP. Esta levedura foi utilizada até recentemente na produção de aguardente na destilaria Prof. Juvenal Mendes de Godoy, da Escola Superior de Agricultura "Luiz de Queiroz". 
3.3 Meio de cultura para manutenção.

Para a manutenção dos microrganismos foram utilizados tubos de ensaio inclinados com o meio de cultura sólido "Yeast extract peptone dextrose agar" (YEPDA), mantidos sob refrigeração a $5^{\circ} \mathrm{C}$. A composição do meio YEPDA utilizado foi a seguinte:

- Extrato de levedura.............................. 1,0\%

- Peptona...................................................... 1,0\%

- Glicose................................................. 2,0\%

- Agar........................................................ 1,5\%

\subsection{Propagação dos microrganismos.}

A propagação da levedura para a obtenção em quantidade suficiente para os ensaios foi realizada em duas fases:

\subsubsection{Fase inicial de propagação dos microrganismos.}

Os tubos com a cultura em YEPDA foram retirados do refrigerador e mantidos a $25^{\circ} \mathrm{C}$ durante 12 horas, para sua ativação. Após este período a multiplicação celular foi iniciada através da inoculação, utilizando três alças de Henle da cultura ativada, em dois litros do meio de cultura "Yeast extract peptone dextrose" (YEPD).

Em seguida, o meio YEPD foi dividido e distribuído em oito erlenmeyers contendo $250 \mathrm{~mL}$ de meio YEPD em cada. Os frascos foram tampados com algodão e mantidos sob agitação constante de $100 \mathrm{rpm}$ durante 24 horas a $25,0 \pm 1,0^{\circ} \mathrm{C}$, realizada em "shaker" modelo DUBNOFF MA-095, marca MARCONI.

A separação da levedura foi realizada por centrifugação a $900 \mathrm{G}$ a $10^{\circ} \mathrm{C}$ durante dez minutos, em centrífuga marca International Refrigerated Centrifuge, 
modelo PR-2.

Nessa fase de propagação do microrganismo foi utilizado o meio YEPD com a seguinte composição:

- Extrato de levedura........................... 1,0\%

- Peptona.............................................. 1,0\%

- Glicose.................................................. 2,0\%

\subsubsection{Fase final de propagação dos microrganismos.}

Para a fase final de produção do microrganismo foi utilizado caldo de cana, porém, foi necessário um preparo prévio do caldo para reduzir a quantidade de impurezas e facilitar a separação da levedura por centrifugação.

O preparo do caldo foi realizado com filtragem e aquecimento até ebulição, mantida durante cinco minutos. Após esse tempo, o aquecimento foi interrompido e o caldo mantido em repouso até o resfriamento para possibilitar a decantação das proteínas coaguladas. Ocorrida a decantação do material protéico realizou-se outra filtração, seguida de diluição para $13,0^{\circ}$ brix e autoclavagem a $121^{\circ} \mathrm{C}$, durante 20 minutos (Ribeiro, 1997).

A seguir, foram transferidos 30 litros de caldo preparado, conforme descrito anteriormente, para dois fermentadores aos quais foram adicionadas as células obtidas na fase inicial de propagação. $O$ mosto foi mantido a temperatura de $25^{\circ} \pm 1^{\circ} \mathrm{C}$, sob a agitação constante de $200 \mathrm{rpm}$ durante 30 horas.

O vinho obtido foi centrifugado para promover a separação das células e a massa celular obtida foi ressuspensa em água destilada e centrifugada por três vezes consecutivas para a separação e purificação do material celular. As células centrifugadas foram utilizadas como inóculo para os ensaios de fermentação.

A multiplicação celular da levedura foi realizada a $25,0^{\circ} \mathrm{C}$, porque, de acordo com Gutierrez (1994), a produção de biomassa é maior nesta temperatura, entretanto, os ensaios de fermentação alcoólica foram conduzidos a $32,0^{\circ} \mathrm{C}$ pois é uma 
temperatura próxima àquelas nas quais ocorrem os processos fermentativos para produção de aguardente .

Os fermentadores utilizados no ensaio foram projetados pelo Prof. Dr. Jorge Horii, do Setor de Açúcar e Álcool da ESALQ-USP, e construídos pela CONGER. São dois conjuntos de fermentadores e cada conjunto possui três dornas de aço inox com capacidade de 15 litros cada. Os fermentadores são providos de sistema de controle de temperatura, que pode variar de $-40 \mathrm{a}+60^{\circ} \mathrm{C}$, e agitador de palhetas com controle de rotação (Boza, 1996).

\subsection{Tratamentos}

O ensaio foi realizado com três tratamentos: um com mosto integral correspondente a testemunha, e outros dois tratamentos com adição de 100 e $150 \mathrm{mg} . \mathrm{L}^{-1}$ de benzoato de sódio, durante 4 ciclos fermentativos, todos em quatro repetições.

\subsection{Condução da fermentação:}

Foram realizados quatro ciclos fermentativos. Para o início do primeiro ciclo fermentativo foram descongelados quatro litros de caldo de cana, e diluídos para $150 \mathrm{~g} . \mathrm{L}^{-1}$ de açúcares redutores totais (ART) com água destilada e esterilizada.

Após a diluição, o caldo foi separado em três frações com $1.200 \mathrm{~mL}$ cada. Duas frações receberam a adição da solução estoque de benzoato de sódio para atingirem a concentração de 100 e $150 \mathrm{mg} . \mathrm{L}^{-1}$, correspondentes ao dois tratamentos. A terceira fração, correspondente à testemunha, não recebeu a adição do sal.

Cada uma das três frações de caldo, com $1.200 \mathrm{~mL}$ cada uma, foi inoculada com a levedura na proporção de $14,0 \mathrm{~g}$ de matéria seca. $\mathrm{L}^{-1}$. Em seguida, foram homogeneizadas com auxílio de agitador magnético e separadas em outras quatro frações de $300 \mathrm{~mL}$ cada, correspondentes às quatro repetições. 
Imediatamente os mostos foram acondicionados em erlenmeyers, previamente marcados, com capacidade de $500 \mathrm{~mL}$, tampados com folhas de alumínio e transferidos para estufa com temperatura controlada de $32,0 \pm 1,0^{\circ} \mathrm{C}$, com agitação ocasional e pesagem de hora em hora. Os três tratamentos foram realizados em quatro repetições, totalizando 12 erlenmeyers.

Ao término da fermentação, evidenciado pelo peso constante durante uma hora, os erlenmeyers foram homogeneizados com agitação e; de cada um, foi retirado $1 \mathrm{~mL}$ para a realização da contagem e a análise da viabilidade dos microrganismos. Em seguida, os vinhos foram centrifugados nas condições descritas anteriormente.

A biomassa centrifugada foi coletada e reutilizadas como inóculo para o ciclo posterior e o vinho delevurado encaminhado para laboratório, onde foi separado em duas frações. Uma porção foi congelada para análise posterior de açúcares residuais e acidez total. A outra foi destilada para as análises de acidez volátil, teor alcoólico e dos componentes quantificados através da cromatografia gasosa.

A partir do final da primeira fermentação foi necessária a alteração de alguns procedimentos, pois a levedura foi centrifugada e reutilizada durante quatro fermentações. As alterações foram: (1) o caldo para cada tratamento foi transferido para os frascos e inoculados com a levedura proveniente do ciclo anterior; (2) a água necessária para diluir o caldo também foi utilizada para promover a lavagem e retirar as células aderidas aos frascos da centrifuga.

Como a levedura foi utilizada durante quatro fermentações sucessivas não foi possivel determinar o peso seco dos microrganismos. Portanto, a matéria seca dos microrganismos foi determinada apenas no início do primeiro ciclo fermentativo.

\subsection{Produção de aguardente}

Na produção das aguardentes foram utilizados 25 litros de caldo para cada tratamento. O caldo foi inoculado, na proporção de $14,0 \mathrm{~g}$ de matéria seca. $\mathrm{L}^{-1}$ e a 
fermentação ocorreu à temperatura ambiente. Duas horas após o término da fermentação, tempo necessário para a decantação de parte da levedura 20 litros de vinho foram transferidos para o alambique.

$O$ aparelho foi aquecido lentamente com fogo direto e o destilado recolhido até que atingisse $45 \%$ de álcool, verificado em densímetro de imersão.

Posteriormente as aguardentes foram diluídas a $40 \%$ de álcool e analisadas através de cromatografia gasosa. Para a realização da análise sensorial as aguardentes foram armazenadas durante um ano.

\subsection{Aparelho de destilação.}

Para a produção de aguardente foi utilizado um alambique de cobre, do tipo conhecido como cebolinha, com capacidade de carga operacional máxima de 25 litros de vinho e aquecimento com fogo direto, procedente dos Laboratórios de Tecnologia de Alimentos da Universidade Estadual de Ponta Grossa (UEPG), Ponta Grossa, PR.

3.9 Solução estoque de benzoato de sódio.

Para a adição do benzoato de sódio ao caldo foi preparada uma solução estoque, com concentração de 50,0g. $\mathrm{L}^{-1}$, dissolvendo-se o sal em água destilada. A solução, preparada no início do ensaio, permaneceu armazenada em geladeira, sendo utilizada durante o ensaio.

\subsection{Matéria seca.}

A determinação da matéria seca do microrganismo foi realizada através de secagem de $1,5 \mathrm{~g}$ de biomassa centrifugada durante 12 minutos, em forno de microondas, 
marca NATIONAL, modelo NE $7660 \mathrm{BH}$, de acordo com metodologia proposta por Sakai (1990).

\subsection{Acompanhamento da fermentação.}

Foi utilizada a pesagem horária dos erlenmeyers contendo o mosto em fermentação, em balança digital marca OHAUS, modelo GT4100,. O término da fermentação ficou estabelecido no momento em que ocorria a repetição do peso entre duas pesagens, segundo procedimento indicado por Copersucar (1987).

\subsection{Acidez volátil do vinho.}

Os teores de ácidos voláteis dos vinhos foram analisados através de destilação por arraste a vapor de $10 \mathrm{~mL}$ de amostra e posterior titulação da fração destilada com solução de $\mathrm{NaOH}, 0,02 \mathrm{~N}$, utilizando fenolftaleína como indicador. Nessa metodologia é necessária a utilização de um fator de correção obtido através da destilação de $10 \mathrm{~mL}$ de uma solução contendo $1,2 \mathrm{~g} \cdot \mathrm{L}^{-1}$ de ácido acético nas mesmas condições descritas anteriormente (Amerine, 1974).

\subsection{Número de células e viabilidade celular.}

A determinação do número total de células e de células viáveis foi realizada através de contagem em Câmara de Neubauer espelhada, utilizando microscópio óptico BH, marca OLYMPUS. As amostras, adequadamente diluídas em água, receberam adição de uma solução de eritrosina para colorir as células inviáveis. As contagens das células foram realizadas em 160 retículos de cada campo da câmara e os resultados de viabilidade celular foram expressos em porcentagem (Copersucar, 1987). 


\subsection{Açúcares totais e residuais.}

Os teores de açúcares redutores totais (ART) no mosto e os açúcares residuais no vinho foram determinados pelo método de Somogyi e Nelson, segundo Bacila (1960). A hidrólise da sacarose foi realizada em 5,0mL de amostra, utilizando $25,0 \mathrm{~mL}$ de ácido clorídrico $1,3 \mathrm{~N}$, mantidos à temperatura entre 60 e $65^{\circ} \mathrm{C}$ durante 30 minutos, seguida de neutralização com hidróxido de sódio $4 \mathrm{~N}$, de acordo com Falcone (1965).

\subsection{Acidez total.}

Determinação segundo o INSTITUTO ADOLFO LUTZ (1985) utilizando $5 \mathrm{~mL}$ de amostra diluída para $100 \mathrm{~mL}$ com água destilada e titulação com solução de $\mathrm{NaOH}, 0,05 \mathrm{~N}$.

\subsection{Etanol.}

Logo após a centrifugação, foram retirados $25 \mathrm{~mL}$ de vinho e as amostras que apresentaram pH inferior a 4,5 receberam a adição de uma solução de $\mathrm{NaOH}, 1 \mathrm{~N}$, em quantidade suficiente para elevar o $\mathrm{pH}$ até 4,5. Esta prática foi adotada para evitar possíveis alterações na densidade do destilado causada pela destilação de ácidos orgânicos. Após a correção do $\mathrm{pH}$, os vinhos foram destilados em microdestilador Kjeldall adaptado para álcool, e a sua densidade determinada em densímetro digital Anton-Paar, modelo DMA-45. A partir da densidade da solução foi estabelecido o teor alcoólico através de tabelas específicas (Barone, 1986). 


\subsection{Compostos voláteis.}

As amostras de vinho foram preparadas utilizando os mesmos procedimentos para a determinação do teor alcoólico. As amostras destiladas foram armazenadas a $5^{\circ} \mathrm{C}$ até a realização das análises cromatográficas, efetuadas no cromatógrafo de fase gasosa, marca CG, modelo 37D, equipado com detector ionização de chama e coluna de aço inoxidável de $3 \mathrm{~m} \times 1 / 8^{\prime \prime}$, contendo Hallcomid M-18 e Carbowax 1500 e padrões internos de etanol a $10 \%$ para as análises nos vinhos. As condições de operação para determinação de álcoois superiores foram as seguintes: temperatura da coluna; $98,0^{\circ} \mathrm{C}$; temperatura do injetor, $140,0^{\circ} \mathrm{C}$; temperatura do detector $250,0^{\circ} \mathrm{C}$; gás de arraste nitrogênio/fluxo $40 \mathrm{~mL}$.min e os volumes injetados de dois microlitros. As análises cromatográficas foram realizadas pela Seção de Cromatografia do Setor de Açúcar e Álcool do Departamento de Ciência e Tecnologia Agroindustrial (Boza, 1996).

Nesta análise, estão estabelecidos como compostos voláteis os ésteres, aldeídos, cetonas e álcoois superiores. Na quantificação de álcoois superiores foram utilizados padrões puros de álcoois n-propílico, isobutilico, n-butílico e isoamílico e namílico.

\subsection{Análise estatística.}

Foi utilizado o delineamento inteiramente casualizado com 4 repetições e para as análises físico-químicas, o teste Tukey, ao nivel de $5 \%$ de significância, segundo Gomes (1990).

\subsection{Análise sensorial.}


com equipe selecionada e Teste de Preferência com equipe não selecionada

O Teste Triangular permite verificar a existência de diferença significativa entre duas aguardentes oriundas de tratamentos diferentes, também possibilita selecionar uma equipe de degustadores. Dessa forma, foi possível selecionar oito provadores, entre 30 pessoas, que conseguiram diferenciar duas aguardentes, ao nível de $5 \%$, de acordo com metodologia recomendada por Dutcosky (1996). O modelo da ficha utilizada está no Apêndice 2.

As avaliações de preferência pelas aguardentes foram realizadas nos Laboratórios de Tecnologia de Alimentos da Universidade Estadual de Ponta Grossa. A equipe de provadores, não selecionados e não treinados, foi constituída por 64 pessoas entre professores e funcionários daquela Instituição. Este teste permite identificar a preferência através de uma escala hedônica de nove pontos (Mori, 1992; Dutcosky, 1996). A escala variou de 1, correspondente a "desgostei muitíssimo", até 9, correspondente a "gostei muitíssimo", conforme o modelo no Apêndice 3. 


\section{RESULTADOS E DISCUSSÃO.}

\subsection{Análises das amostras dos vinhos}

\subsubsection{Acidez total e volátil}

Na tabela 8, e no apêndice 4, estão apresentados os resultados obtidos do efeito da adição do benzoato de sódio sobre a acidez titulável total dos vinhos. No primeiro ciclo fermentativo não ocorreram diferenças significativas entre os tratamentos, entretanto, a adição do benzoato de sódio promoveu um aumento significativo na acidez dos vinhos. A partir do segundo ciclo fermentativo, o aumento foi proporcional à quantidade de inibidor adicionado.

É possível observar que no tratamento testemunha, a variação da acidez total não foi elevada como nos demais tratamentos. A causa da elevação de $3,999 \mathrm{~g} \cdot \mathrm{L}^{-1}$ para $9,217 \mathrm{~g} \cdot \mathrm{L}^{-1}$ no tratamento com $100 \mathrm{mg} \cdot \mathrm{L}^{-1}$ do inibidor e de $3,997 \mathrm{~g} . \mathrm{L}^{-1}$ para $10,801 \mathrm{~g} \cdot \mathrm{L}^{-1}$ naquele com $150 \mathrm{mg} . \mathrm{L}^{-1}$ foi, provavelmente, devido ao desenvolvimento de bactérias contaminantes. As bactérias possivelmente foram recicladas, juntamente com as leveduras, no processo de separação por centrifugação e reinoculadas nos ciclos posteriores.

Analisando os resultados do efeito do sal na produção de ácidos voláteis (Tabela 9 e apêndice 5), é possivel observar que a presença do inibidor causou um aumento significativo dos teores de ácidos voláteis já a partir do primeiro ciclo fermentativo. As diferenças entre os tratamentos foram mantidas significativas até o quarto ciclo.

Comparando-se os resultados apresentados nas tabelas 8 e 9 observa-se a 
relação existente entre a acidez total e a acidez volátil, com um coeficiente de correlação entre as duas características de 0,83 para o tratamento testemunha; 0,98 para o tratamento com $100 \mathrm{mg} \cdot \mathrm{L}^{-1}$ do sal e 0,97 para aquele com $150 \mathrm{mg} . \mathrm{L}^{-1}$. As elevadas correlações existentes entre as duas características estudadas revelam que, apesar das diferentes concentrações, a elevação nos teores de ambas foi relativamente semelhante. Portanto, pode-se perceber que houve a produção de vários ácidos e não apenas de ácidos voláteis.

Tabela 8. Efeito da adição de benzoato de sódio na formação de ácidos orgânicos, em g. $L^{-1}$, expressos em ácido acético, médias de quatro repetições.

\begin{tabular}{ccccc}
\hline tratamentos & $1^{\circ}$ ciclo & $2^{\mathbf{o}}$ ciclo & $3^{\circ}$ ciclo & $4^{\mathrm{o}}$ ciclo \\
\hline testemunha & $3,990^{\mathrm{a}}$ & $3,97^{\mathrm{c}}$ & $3,988^{\mathrm{c}}$ & $4,019^{\mathrm{c}}$ \\
100mg.L-1 & $3,999^{\mathrm{a}}$ & $5,197^{\mathrm{b}}$ & $6,557^{\mathrm{b}}$ & $9,217^{\mathrm{b}}$ \\
150mg.L-1 & $3,997^{\mathrm{a}}$ & $5,830^{\mathrm{a}}$ & $8,892^{\mathrm{a}}$ & $10,801^{\mathrm{a}}$ \\
\hline dms 5\% & 0,024 & 0,193 & 0,084 & 0,051 \\
c.v. (\%) & 0,311 & 1,958 & 0,656 & 0,323 \\
\hline
\end{tabular}

médias seguidas por letras distintas no sentido vertical diferem entre si ao nível de significância indicado

Alves (1994) relata que em leveduras, o ácido succínico pode ser produzido por duas vias: a redutiva e a oxidativa, sendo a última a prioritária. $\mathrm{Na}$ via oxidativa o piruvato é carboxilado até oxaloacetato, que por sua vez, condensa com acetil-coenzima-A até citrato, passando sucessivamente a isocitrato, alfa-cetoglutarato, succinil-coenzima-A e finalmente succinato.

Como consequiência do uso do benzoato de sódio ocorre a redução na formação de acetil-coenzima-A e, consequentemente, a etapa na qual o oxaloacetato deve condensar com acetil-coenzima-A fica prejudicada e dessa forma a produção de ácido succínico é reduzida.

Apesar do benzoato de sódio promover redução na formação de ácido succínico houve uma elevação da concentração de ácidos orgânicos nos tratamentos com o sal. Esse fato foi, provavelmente, uma conseqüência do desenvolvimento de 
bactérias contaminantes que produziram ácidos.

Os resultados obtidos de acidez total e volátil são superiores, mesmo no tratamento testemunha, aos obtidos por Ribeiro (1997), que avaliou a fermentação de caldo de cana por três linhagens de Saccharomyces cerevisiae e relatou valores de acidez volátil de $379 \mathrm{mg} . \mathrm{L}^{-1}$ para uma linhagem floculante (LF), $458 \mathrm{mg} . \mathrm{L}^{-1}$ para a linhagem IZ987 e $504 \mathrm{mg} . \mathrm{L}^{-1}$ para a isolada de fermento prensado (LP).

Tabela 9. Efeito da adição de benzoato de sódio na formação de ácidos voláteis, em g.L-1, expressos em ácido acético, médias de quatro repetições.

\begin{tabular}{ccccc}
\hline tratamentos & $1^{\circ}$ ciclo & $2^{\mathrm{o}}$ ciclo & $3^{\mathrm{o}}$ ciclo & $4^{\mathrm{o}}$ ciclo \\
\hline testemunha & $0,546^{\mathrm{c}}$ & $0,550^{\mathrm{c}}$ & $0,718^{\mathrm{c}}$ & $0,735^{\mathrm{c}}$ \\
$100 \mathrm{mg} \cdot \mathrm{L}^{-1}$ & $0,765^{\mathrm{b}}$ & $0,932^{\mathrm{b}}$ & $1,236^{\mathrm{b}}$ & $1,495^{\mathrm{b}}$ \\
& $0,825^{\mathrm{a}}$ & $1,056^{\mathrm{a}}$ & $1,624^{\mathrm{a}}$ & $1,641^{\mathrm{a}}$ \\
\hline 150mg.L & 0,153 & 0,068 & 0,060 & 0,032 \\
\hline dms $5 \%$ & 1,089 & 4,084 & 2,579 & 1,266 \\
\hline
\end{tabular}

médias seguidas por letras distintas no sentido vertical diferem entre si ao nível de significância indicado

\subsubsection{Contagem total e viabilidade celular}

Outras consequêencias do uso do inibidor na fermentação alcoólica podem ser observadas na Tabela 10 e no apêndice 6, que demonstram duas características importantes. A primeira é o efeito sobre a viabilidade celular e a segunda, o efeito sobre o número de células. $\mathrm{mL}^{-1}$.

No tratamento testemunha, a redução do número de células.mL-1 foi menor que nos tratamentos com o sal, entretanto, na viabilidade celular a redução foi elevada, chegando a apenas $53,1 \%$ ao final do quarto ciclo fermentativo. A análise dos resultados apresentados revela que a condução do ensaio não favoreceu o desenvolvimento da levedura, mesmo para o tratamento testemunha, e sugere que o uso do inibidor deve ser estudado com outras linhagens de leveduras, melhores 
adaptadas a metodologia utilizada neste ensaio.

Nos tratamentos com o sal pode-se observar que o uso do inibidor causou redução significativa entre os tratamentos, em todos os ciclos fermentativos, nos dois parâmetros em questão, sendo a redução proporcional à quantidade de inibidor utilizado. Um fator muito importante na contagem de células e viabilidade celular foram as dificuldades ocorridas durante a realização dos ensaios que impossibilitaram o acompanhamento adequado dessas características. Portanto não foram realizadas contagens no início e final de cada ciclo fermentativo, mas apenas no final.

A ausência das análises de contagem de células e viabilidade celular no início dos ciclos fermentativos impede a discussão sobre o efeito do sal em cada ciclo, entretanto, os resultados verificados ao final dos ciclos fermentativos demonstram uma tendência para os tratamentos. No momento da inoculação para o primeiro ciclo fermentativo os tratamentos continham, em média, $1,25 \times 10^{9}$ células.mL-1 ${ }^{-1}$ com $95,0 \%$ de viabilidade e pode-se observar uma redução no número e na viabilidade em todos os tratamentos, contudo, os tratamentos com o sal tiveram maiores reduções em ambas as caracteristicas, demonstrando um efeito negativo do seu uso.

Tabela 10. Efeitos da adição de benzoato de sódio sobre o número total de células (células. $\mathrm{mL}^{-1}$ ) e viabilidade celular (\%), médias de quatro repetiçōes.

\begin{tabular}{|c|c|c|c|c|}
\hline & $1^{\circ}$ ciclo & $2^{\circ}$ ciclo & $3^{\circ}$ ciclo & $4^{\circ}$ ciclo \\
\hline tratamentos & células.mL-1 \% & células.mL-1 \% & células.mL-1 \% & células.mL-1 \% \\
\hline testemunha & $1,30 \times 10^{9}$ a 89,5 & $1,30 \times 10^{9}$ a 84,2 & $1,24 \times 10^{9}$ a 73,4 & $1,17 \times 10^{9}$ a 53,1 \\
\hline 100mg. $\mathrm{L}^{-1}$ & $1,11 \times 10^{9}$ b 87,8 & $1,00 \times 10^{9}$ b $\quad 68,1$ & $9,21 \times 10^{8}$ b $\quad 48,0$ & $8,25 \times 10^{8}$ b 32,2 \\
\hline 150mg.L-1 & $1,04 \times 10^{9 b} 88,5$ & $8,98 \times 10^{8}$ c 66,5 & $7,34 \times 10^{8}$ c 43,9 & $6,86 \times 10^{8} \mathrm{c} \quad 14,3$ \\
\hline dms 5\% & $1,47 \times 10^{8}$ & $9,98 \times 10^{7}$ & $1,17 \times 10^{8}$ & $1,19 \times 10^{8}$ \\
\hline c.v. $(\%)$ & 0,266 & 1,869 & 1,768 & 1,178 \\
\hline
\end{tabular}

médias seguidas por letras distintas no sentido vertical diferem entre si ao nível de significância indicado

A utilização do benzoato como inibidor de crescimento celular durante a fermentação alcoólica promove menores produções de acetil-coenzima-A, necessária 
para a síntese do ácido alfacetoisocapróico, e consequentemente reduz a produção da leucina, da mesma forma reduz a produção de ácido aspártico que é um dos precursores da treonina. A redução nos teores de leucina, aspártico e treonina, entre outros aminoácidos, tem como conseqüência a menor produção de massa celular. Uma pequena redução do crescimento celular é um fato desejável, pois o substrato que seria usado para este fim pode ser utilizado na produção de etanol e assim, aumentar a eficiência e o rendimento fermentativo.

Os efeitos da ação do benzoato de sódio como inibidor de crescimento celular já haviam sido pesquisados por Gutierrez et al (1991) que testou o sal em fermentação de mosto de melaço com a levedura industrial Saccharomyces cerevisiae M300-A e não observou queda significativa na viabilidade celular, mantendo-se próxima a $95 \%$ durante oito ciclos fermentativos. Naquele ensaio o pesquisador utilizou meio de melaço suplementado, com $150 \mathrm{ppm}$ de nitrogênio amoniacal na forma de sulfato de amônio e 100ppm de fósforo na forma de fostato dibásico de potássio, e esterilizado em autoclave e dessa forma não ocorreu competição com microrganismos contaminantes, fato que também pode reduzir a viabilidade da levedura. A diferença de comportamento pode ser explicada pela composição do meio, pois o melaço é mais rico em nutrientes, comparativamente, ao caldo de cana e dessa forma reduz a ação do inibidor.

Apesar do benzoato de sódio ser considerado um inibidor de crescimento de microrganismos de ação mais efetiva contra leveduras que bactérias, os resultados obtidos nesse ensaio sugerem a necessidade de controle de microrganismos indesejáveis no processo fermentativo.

\subsubsection{Consumo de açúcares}

O efeito do sal sobre o consumo de açúcares foi a característica que apresentou maior variação, não apenas entre tratamentos mas também entre os ciclos fermentativos, fato demonstrado pelo elevado coeficiente de variação. No primeiro 
ciclo, somente o tratamento que recebeu $100 \mathrm{mg} \cdot \mathrm{L}^{-1}$ de benzoato de sódio teve um aumento significativo no consumo de açúcares em relação aos demais. No segundo e terceiro ciclo, o tratamento com $150 \mathrm{mg} \cdot \mathrm{L}^{-1}$ foi significativamente menor, já no quarto ciclo todos os tratamentos foram significativamente diferentes.

Quando comparadas as concentrações de açúcares residuais aos vinhos (Tabela 11 e apêndice 7), no último ciclo observa-se que foram relativamente maiores nos tratamentos que receberam o inibidor, fato que indica a existência de algum fator que causou menor atividade fermentativa da levedura e impossibilitou o consumo total dos açúcares presentes no mosto. A diferença nas concentrações de açúcares residuais foi cerca de 10 vezes maior no tratamento que recebeu $100 \mathrm{mg}$. $\mathrm{L}^{-1}$ e 15 vezes no tratamento com $150 \mathrm{mg} \cdot \mathrm{L}^{-1}$ do inibidor, em relação ao tratamento testemunha.

A redução no consumo de açúcares é um fato indiscutivelmente indesejável pois reduz o rendimento fermentativo e pode ter como prováveis responsáveis, a contaminação bacteriana e a elevação na acidez.

Os resultados obtidos no tratamento testemunha são próximos dos resultados divulgados por Ribeiro (1997), que verificou $0,733 \mathrm{~g}$. $\mathrm{L}^{-1}$ para o tratamento com a LF; $0,700 \mathrm{~g} \cdot \mathrm{L}^{-1}$ no tratamento com IZ-987 e 3,120g. $\mathrm{L}^{-1}$ naquele com a LP.

Tabela 11. Açúcares residuais, em $g \cdot \mathrm{L}^{-1}$ expressos em glucose, médias de quatro repetições.

\begin{tabular}{ccccc}
\hline tratamentos & $1^{\circ}$ ciclo & $2^{\circ}$ ciclo & $3^{\circ}$ ciclo & $4^{\circ}$ ciclo \\
\hline testemunha & $0,794^{\mathrm{a}}$ & $0,750^{\mathrm{b}}$ & $0,744^{\mathrm{b}}$ & $0,759 \mathrm{c}$ \\
100mg. $\mathrm{L}^{-1}$ & $0,572^{\mathrm{b}}$ & $0,554^{\mathrm{b}}$ & $0,635^{\mathrm{b}}$ & $7,720^{\mathrm{b}}$ \\
150mg. $\mathrm{L}^{-1}$ & $0,767^{\mathrm{a}}$ & $4,051^{\mathrm{a}}$ & $5,123^{\mathrm{a}}$ & $11,830^{\mathrm{a}}$ \\
\hline dms 5\% & 0,109 & 1,069 & 1,373 & 3,083 \\
c.v. (\%) & 7,809 & 30,341 & 32,090 & 23,060 \\
\hline médias seguidas por letras distintas no sentido vertical diferem entre si ao nível de significância indicado
\end{tabular}




\subsubsection{Etanol e eficiência fermentativa}

Devido a relação existente entre o consumo de açúcares e a formação de etanol, a produção deste também foi uma característica que apresentou grande variação (Tabela 12 e apêndice 8). No primeiro e no segundo ciclo, a produção de álcool foi significativamente maior nos dois tratamentos que receberam adição do benzoato, em relação ao tratamento testemunha. No quarto ciclo, todos os tratamentos diferiram significativamente entre si, sendo o tratamento testemunha o melhor $\left(64,7 \mathrm{~g} . \mathrm{L}^{-1}\right)$, seguido do tratamento com $100 \mathrm{mg} . \mathrm{L}^{-1}$ do inibidor $\left(63,0 \mathrm{~g} \cdot \mathrm{L}^{-1}\right)$ e por último aquele com $150 \mathrm{mg} \cdot \mathrm{L}^{-1}$ do sal $\left(57,9 \mathrm{~g} \cdot \mathrm{L}^{-1}\right)$.

Os resultados das adições do sal até o segundo ciclo fermentativo estavam favorecendo a produção de álcool, contudo, a partir do terceiro ciclo o uso contínuo do sal prejudicou a atividade das leveduras, consequentemente, a produção de álcool foi menor e o teor alcoólico dos vinhos passou a ser significativamente inferior ao tratamento testemunha.

Os resultados obtidos são contrários àqueles obtidos por Gutierrez et al (1991), em fermentação de melaço, em que o uso do inibidor promoveu um aumento na produção de etanol.

Tabela 12. Teor alcoólico dos vinhos após fermentações realizadas com 0, 100 e $150 \mathrm{mg} . \mathrm{L}^{-1}$ de benzoato de sódio, em g.L-1, médias de quatro repetições.

\begin{tabular}{|c|c|c|c|c|}
\hline tratamentos & $1^{\circ}$ ciclo & $2^{\circ}$ ciclo & $3^{\circ}$ ciclo & $4^{\circ}$ ciclo \\
\hline testemunha & $64,4^{b}$ & $64,5^{b}$ & $64,1^{\mathrm{a}}$ & $64,7^{\mathrm{a}}$ \\
\hline 100mg.L-1 & $65,5^{a}$ & $67,7^{\mathrm{a}}$ & $63,5^{a}$ & $63,0^{b}$ \\
\hline 150mg. $\mathrm{L}^{-1}$ & $65,6^{a}$ & $66,6^{a}$ & $61,2^{b}$ & $57,9 \mathrm{c}$ \\
\hline $\operatorname{dms} 5 \%$ & 0,343 & 0,847 & 2,332 & 1,439 \\
\hline c.v. (\%) & 0,266 & 0,647 & 1,876 & 1,179 \\
\hline
\end{tabular}

médias seguidas por letras distintas no sentido vertical diferem entre si ao nível de significância indicado

A eficiência de fermentação (Tabela 13), entendida como eficiência de 
transformação do substrato em produto, da testemunha, foi constante durante os quatro ciclos e apresentou a média de $84,48 \%$. Por sua vez, o tratamento com $100 \mathrm{mg}$. $\mathrm{L}^{-1}$, quando comparado com a testemunha, possibilitou uma maior eficiência no primeiro e segundo ciclo, foi menor no terceiro ciclo e voltou a ser maior no quarto ciclo, sendo a média de $86,07 \%$. O último tratamento apresentou comportamento similar, foi maior no primeiro e no segundo ciclo e menor nos demais e terminou com a média de $85,00 \%$.

A eficiência de fermentação com base no rendimento proveniente da equação de Gay-Lussac (51,1g de etanol.100g de glicose-1), é calculada pela equação:

$$
\text { eficiência de fermentação }=\frac{(P / S) \times 100}{51,1}
$$

em que: $P=$ etanol produzido, em $g \cdot L^{-1}$.

$S=$ açúcar consumido, em g.L-1.

Tabela 13. Eficiência de fermentação, com base no rendimento proveniente da equação de Gay-Lussac (51,1g de etanol.100g de glicose), médias de quatro repetições.

\begin{tabular}{ccccc}
\hline tratamentos & $1^{\circ}$ ciclo & $2^{\circ}$ ciclo & $3^{\circ}$ ciclo & $4^{\circ}$ ciclo \\
\hline testemunha & 84,47 & 84,57 & 84,04 & 84,84 \\
100mg.L ${ }^{-1}$ & 85,78 & 88,65 & 83,20 & 86,65 \\
150mg.L ${ }^{-1}$ & 86,02 & 89,30 & 82,67 & 82,01 \\
\hline
\end{tabular}

Gutierrez (1989) verificou eficiência fermentativa de $91,60 \%$ para a Saccharomyces cerevisiae - IZ 1904, em meio de melaço diluído para $140 \mathrm{~g}$ de ART.L-1, enquanto que Ribeiro (1997) divulgou valores, em fermentação de caldo de cana, de $83,21 \%$ para a LF; 89,94 para a linhagem IZ-987 e $86,01 \%$ para a FP. 


\subsubsection{Tempo de fermentação}

A ação inibidora do sal sobre as leveduras pode ser facilmente percebida quando são comparados os tempos necessários para que fosse verificado o final do processo fermentativo (Tabela 14 e apêndice 9). Pode-se perceber que no primeiro ciclo todos os tratamentos encerraram a fermentação em 12 horas, tempo que foi mantido pelo tratamento testemunha durante os quatro ciclos. A partir do segundo ciclo todos os tratamentos foram significativamente diferentes; o tratamento com $100 \mathrm{mg} . \mathrm{L}^{-1} \mathrm{de}$ benzoato apresentou um aumento no tempo de fermentação, terminado o quarto ciclo em 17 horas, enquanto que o tratamento com $150 \mathrm{mg} \cdot \mathrm{L}^{-1}$ de benzoato encerrou a fermentação 33 horas após o início. A fermentação foi muito mais lenta nos tratamentos com o sal que no tratamento testemunha, como conseqüência, a produtividade do processo foi reduzida, o que é um fato indesejável para produtores de aguardentes.

Tabela 14. Efeito da adição de benzoato de sódio no tempo de fermentação, em horas, médias de quatro repetições.

\begin{tabular}{ccccc}
\hline tratamentos & $1^{\circ}$ ciclo & $2^{\circ}$ ciclo & $3^{\circ}$ ciclo & $4^{\circ}$ ciclo \\
\hline testemunha & 12,00 & $12,00^{\mathrm{c}}$ & $12,00^{\mathrm{c}}$ & $12,00^{\mathrm{c}}$ \\
100mg.L-1 & 12,00 & $13,00^{\mathrm{b}}$ & $14,00^{\mathrm{b}}$ & $17,00^{\mathrm{b}}$ \\
150mg.L-1 & 12,00 & $14,00^{\mathrm{a}}$ & $20,00^{\mathrm{a}}$ & $33,00^{\mathrm{a}}$ \\
\hline dms 5\% & - & 0,570 & 0,806 & 1,091 \\
c.v. (\%) & - & 2,235 & 32,692 & 2,686 \\
\hline
\end{tabular}

médias seguidas por letras distintas no sentido vertical diferem entre si ao nível de significância indicado

O aumento no tempo necessário para encerrar o processo fermentativo pode ter várias causas e entre as mais prováveis destacam-se a elevação nos teores de acidez volátil e total e a redução na viabilidade celular. Entretanto, a viabilidade celular pareceu influir pouco, pois no tratamento testemunha, apesar da queda da viabilidade celular, o tempo de fermentação foi mantido constante durante os quatro ciclos fermentativos. 


\subsection{6 Álcoois superiores}

A redução na formação dos álcoois superiores n-propílico, isoamílico e isobutílico é o principal interesse na utilização do benzoato de sódio em processos fermentativos, principalmente a redução do isoamílico que é o álcool sụperior presente em maior quantidade na aguardente, muitas vezes, correspondendo a mais de $50 \%$ do total de álcoois superiores presentes na bebida.

A Tabela 15 e o apêndice 10 demonstram que a formação do álcool npropílico não diferiu significativamente em nenhum ciclo de qualquer tratamento, embora possa ser observada uma tendência de aumento no tratamento que recebeu $150 \mathrm{mg} . \mathrm{L}^{-1}$ do inibidor; a concentração passou de $0,60 \mathrm{mg} \cdot \mathrm{L}^{-1}$ no primeiro ciclo para 1,16mg.L-1 no último.

Outra característica interessante observada na análise desse componente foram as elevadas variações nas concentrações apresentadas pelas repetições, fato comprovado pelo alto coeficiente de variação, que variou de $35,742 \%$ no segundo ciclo até $57,989 \%$ no primeiro ciclo fermentativo.

Tabela 15. Teores de álcool n-propílico nos vinhos, em mg.100mL-1, médias de quatro repetições.

\begin{tabular}{ccccc}
\hline Tratamentos & $1^{\circ}$ ciclo & $2^{\circ}$ ciclo & $3^{\circ}$ ciclo & $4^{\circ}$ ciclo \\
\hline Testemunha & $0,83^{\mathrm{a}}$ & $0,65^{\mathrm{a}}$ & $0,62^{\mathrm{a}}$ & $0,73^{\mathrm{a}}$ \\
100mg.L-1 & $0,63^{\mathrm{a}}$ & $0,71^{\mathrm{a}}$ & $0,45^{\mathrm{a}}$ & $0,74^{\mathrm{a}}$ \\
150mg.L-1 & $0,60^{\mathrm{a}}$ & $0,67^{\mathrm{a}}$ & $0,84^{\mathrm{a}}$ & $1,16^{\mathrm{a}}$ \\
\hline Dms 5\% & 0,786 & 0,476 & 0,711 & 0,882 \\
c.v. (\%) & 57,989 & 35,742 & 56,558 & 51,041 \\
\hline
\end{tabular}

médias seguidas por letras distintas no sentido vertical diferem entre si ao nível de significância indicado

Gutierrez et al (1991) relatou que a adição de $150 \mathrm{mg} \cdot \mathrm{L}^{-1}$ de benzoato de sódio em mosto de melaço corrigido para 15,0\% de açúcares redutores totais e $\mathrm{pH} 4,0$, durante quatro e seis ciclos fermentativos, promoveu redução nos teores do álcool n- 
propílico ( 50,60 para 26,70 e $19,30 \mathrm{mg} \cdot \mathrm{L}^{-1}$ respectivamente), isobutilico ( 54,30 para 47,30 e 39,30$)$ e isoamílico $\left(79,50\right.$ para 61,20 e $\left.52,70 \mathrm{mg}^{-L^{-1}}\right)$ em vinhos com 8,07 e $8,12 \%$ de etanol (vol/vol).

Os resultados obtidos neste ensaio contrariam àqueles publicados por Gutierrez et al (1991) quando a adição do inibidor causou redução significativa do álcool n-propílico. Porém, cabe aqui ressaltar que os pesquisadores utilizaram melaço de cana, que contém maiores teores de aminoácidos que o caldo de cana. A diferença na concentração de aminoácidos presentes na matéria-prima pode alterar o metabolismo da levedura e possibilitar a diferença de comportamento verificada entre os dois casos.

Os teores de álcool n-propílico detectados neste ensaio foram bastante reduzidos em relação aos apresentados na literatura. Ribeiro (1997) verificou concentrações de n-propílico na ordem de $27,40 \mathrm{mg}^{\mathrm{L}^{-1}}$ no vinho fermentado pela LF; $25,53 \mathrm{mg} \cdot \mathrm{L}^{-1}$ no vinho com a IZ-987 e 20,50mg. $\mathrm{L}^{-1}$ no vinho com a FP. É importante citar que o teor alcoólico dos vinhos obtido por Ribeiro (1997) foram inferiores àqueles obtidos neste ensaio. O pesquisador divulgou valores de $54,51 \mathrm{~g}$ de etanol. $\mathrm{L}^{-1}$ no vinho fermentado pela levedura LF, 59,91g de etanol. $\mathrm{L}^{-1}$ naquele fermentado pela IZ-987 e $57,60 \mathrm{~g}$ de etanol.L-1 pela FP

Os efeitos do inibidor na formação dos álcoois isoamílico e isobutílico podem ser observados nas Tabelas 16 e 17 e nos apêndices 11 e 12 . Comparando as duas tabelas, pode-se observar a semelhança existente entre os resultados dos dois casos. Nos tratamentos que receberam o benzoato de sódio ocorreram reduções na produção desses álcoois, tanto a concentração de álcool isoamílico quanto a de álcool isobutílico. A produção foi significativamente menor que o tratamento testemunha em todos os ciclos fermentativos.

Quando comparados os dois tratamentos com o sal observa-se que, aquele que recebeu $150 \mathrm{mg} \cdot \mathrm{L}^{-1}$ de benzoato de sódio, a produção do álcool isoamílico foi significativamente reduzida somente no primeiro e último ciclo fermentativo, nos demais ciclos não foram detectadas diferenças estatísticas. 
Tabela 16. Concentrações do álcool isoamílico nos vinhos, em mg.100mL-1, médias de quatro repetições.

\begin{tabular}{|c|c|c|c|c|}
\hline Tratamentos & $1^{\circ}$ ciclo & $2^{\circ}$ ciclo & $3^{\circ}$ ciclo & $4^{\circ}$ ciclo \\
\hline Testemunha & $13,65^{a}$ & $13,38^{a}$ & $12,99 \mathrm{a}$ & $12,86^{a}$ \\
\hline 100mg.L $\mathrm{L}^{-1}$ & $11,54^{b}$ & $8,58^{b}$ & $8,44^{b}$ & $8,83^{b}$ \\
\hline 150mg.L-1 & $10,36^{c}$ & $7,11^{b}$ & $8,17^{b}$ & $6,01^{c}$ \\
\hline Dms 5\% & 1,126 & 2,320 & 4,067 & 1,652 \\
\hline c.v. (\%) & 4,812 & 12,122 & 22,462 & 9,059 \\
\hline
\end{tabular}

médias seguidas por letras distintas no sentido vertical diferem entre si ao nível de significância indicado

A redução da produção do álcool isoamílico é devido a menor formação de acetil-coenzima-A necessária para a síntese do ácido alfacetoisocapróico, consequentemente ocorre redução na formação de leucina e do álcool isoamílico.

A Tabela 17 mostra os dados sobre os teores de álcool isobutílico, os resultados demonstram que entre os dois tratamentos com o sal somente ocorreu diferença significativa no primeiro ciclo e nos demais ciclos não houve diferenças. Interessante que não foi verificada diferença estatística entre o tratamento testemunha e aquele com 100mg. $\mathrm{L}^{-1}$ do sal inibidor no último ciclo .

Tabela 17. Concentrações de álcool isobutílico nos vinhos, em mg.100 $\mathrm{mL}^{-1}$, médias de quatro repetições.

\begin{tabular}{|c|c|c|c|c|}
\hline Tratamentos & $1^{\circ}$ ciclo & $2^{\circ}$ ciclo & $3^{\circ}$ ciclo & $4^{\circ}$ ciclo \\
\hline Testemunha & $4,82 \mathrm{a}$ & $4,60^{a}$ & $3,23 \mathrm{a}$ & $3,80^{a}$ \\
\hline 100mg.L-1 & $3,63^{b}$ & $2,52^{b}$ & $1,76^{b}$ & $2,55 \mathrm{ab}$ \\
\hline 150mg. L-1 & $3,18^{c}$ & $2,08^{b}$ & $1,67^{b}$ & $1,44^{\mathrm{b}}$ \\
\hline Dms 5\% & 0,359 & 0,650 & 1,182 & 1,546 \\
\hline c.v. (\%) & 4,697 & 10,743 & 29,857 & 30,184 \\
\hline
\end{tabular}

médias seguidas por letras distintas no sentido vertical diferem entre si ao nível de significância indicado 
A análise dos resultados obtidos no segundo ciclo fermentativo demonstrou uma redução de $46,8 \%$ na concentração de álcool isoamílico e $54,8 \%$ de álcool isobutílico no tratamento com $150 \mathrm{mg} \cdot \mathrm{L}^{-1}$ de inibidor e de $35,8 \%$ e $45,2 \%$, respectivamente, no tratamento com $100 \mathrm{mg} . \mathrm{L}^{-1}$. Nos ciclos seguintes, a produção dos álcoois isoamílico e isobutílico foi pouco reduzida. Os resultados verificados tornam interessante a realização de novos estudos com o uso do sal em adições parceladas ou alternadas, possibilitando economia em relação às adições contínuas utilizadas neste ensaio.

No final do quarto ciclo podemos observar que houve uma redução no total de álcoois superiores de $30,30 \%$, no tratamento com $100 \mathrm{mg} \cdot \mathrm{L}^{-1}$ e $51,49 \%$, no tratamento com $150 \mathrm{mg} \cdot \mathrm{L}^{-1}$ de inibidor.

A redução nos teores de álcoois superiores seguem a tendência apresentada por Gutierrez et al (1991), e as concentrações dos álcoois superiores são inferiores às publicadas por Ribeiro (1997), que foram de 62,70 e 28,20 $\mathrm{mg} \cdot \mathrm{L}^{-1}$ de álcool isoamílico e isobutilico, respectivamente, para a LF, 115,83 e 43,83mg.L-1 para a IZ-987 e 38,10 e 23,70mg.L-1 para a FP. O teor alcoólico dos vinhos obtidos por Ribeiro (1997) foram os mesmos citados anteriormente.

As análises cromatográficas não detectaram presença dos álcoois $\mathbf{n}$ butílico e n-amílico em nenhum dos tratamentos.

\subsection{Análises das amostras de aguardentes}

A composição das aguardentes produzidas (Tabela 18) demonstra que a utilização de benzoato de sódio promoveu uma elevação nos teores do álcool $n$-butílico e redução nos teores dos álcoois n-propílico, isobutílico e no isoamílico. Também é possível observar que a adição de benzoato de sódio possibilitou uma redução no teor total de álcoois superiores, de $326,77 \mathrm{mg} \cdot 100 \mathrm{~mL}^{-1}$ de álcool anidro na testemunha, para $271,78 \mathrm{mg} \cdot 100 \mathrm{~mL}^{-1}$ de álcool anidro, correspondente a $16,8 \%$, no tratamento com $100 \mathrm{mg} \cdot \mathrm{L}^{-1}$ de inibidor e $241,29 \mathrm{mg} \cdot 100 \mathrm{~mL}^{-1}$ de álcool anidro, equivalente a $26,2 \%$, no 
tratamento com 150mg. $\mathrm{L}^{-1}$. Todas as aguardentes analisadas continham $40 \%$ de álcool.

A redução dos teores de álcoois superiores não foi tão elevada quanto ao ensaio de bancada, contudo, ficou demonstrada a eficiência do benzoato de sódio como inibidor de formação de álcoois superiores.

Tabela 18. Análise cromatográfica das aguardentes produzidas em alambique, em mg.100 $\mathrm{mL}^{-1}$ de álcool anidro, médias de duas repetições.

\begin{tabular}{lrrr}
\hline componente & testemunha & $100 \mathrm{mg} \cdot \mathrm{L}^{-1}$ & $150 \mathrm{mg} \cdot \mathrm{L}^{-1}$ \\
\hline aldeídos & 5,75 & 5,85 & 7,26 \\
acetona & 0,55 & 0,64 & 0,74 \\
ésteres & 14,61 & 39,05 & 19,35 \\
metanol & 3,52 & 3,44 & 4,36 \\
n-propílico & 8,18 & 6,55 & 7,20 \\
isobutílico & 71,65 & 56,00 & 48,72 \\
n-butílico & 0,23 & 1,04 & 0,74 \\
isoamílico & 246,71 & 208,19 & 184,63 \\
álcoois superiores & 326,77 & 271,78 & 241,29 \\
\hline
\end{tabular}

A Figura 1 demonstra um fato interessante, apenas no tratamento testemunha a concentração de álcoois superiores ultrapassou $300 \mathrm{mg} .100 \mathrm{~mL}^{-1}$ de álcool anidro, ou seja, o limite máximo estabelecido pela Legislação Nacional. Na mesma figura pode-se observar que as concentrações de álcoois superiores foram reduzidas nos tratamentos com o benzoato de sódio, contudo, as proporções entre os álcoois superiores foram muito semelhantes, ou seja, 75,50 a 76,60\% de álcool isoamílico, 20,19 a 21,93 de álcool isobutílico, 2,41 a 2,98\% de n-propílico e 0,07 a 0,38\% de n-butílico.

Stupiello (1992) analisou 185 amostras de aguardentes de várias origens e constatou que $28 \%$ das amostras continham concentrações de álcoois superiores entre 300,00 e $350,00 \mathrm{mg} .100 \mathrm{~mL}^{-1}$ de álcool anidro e a amostra com a maior concentração de álcoois superiores continha $825 \mathrm{mg} .100 \mathrm{~mL}^{-1}$ de álcool anidro. 


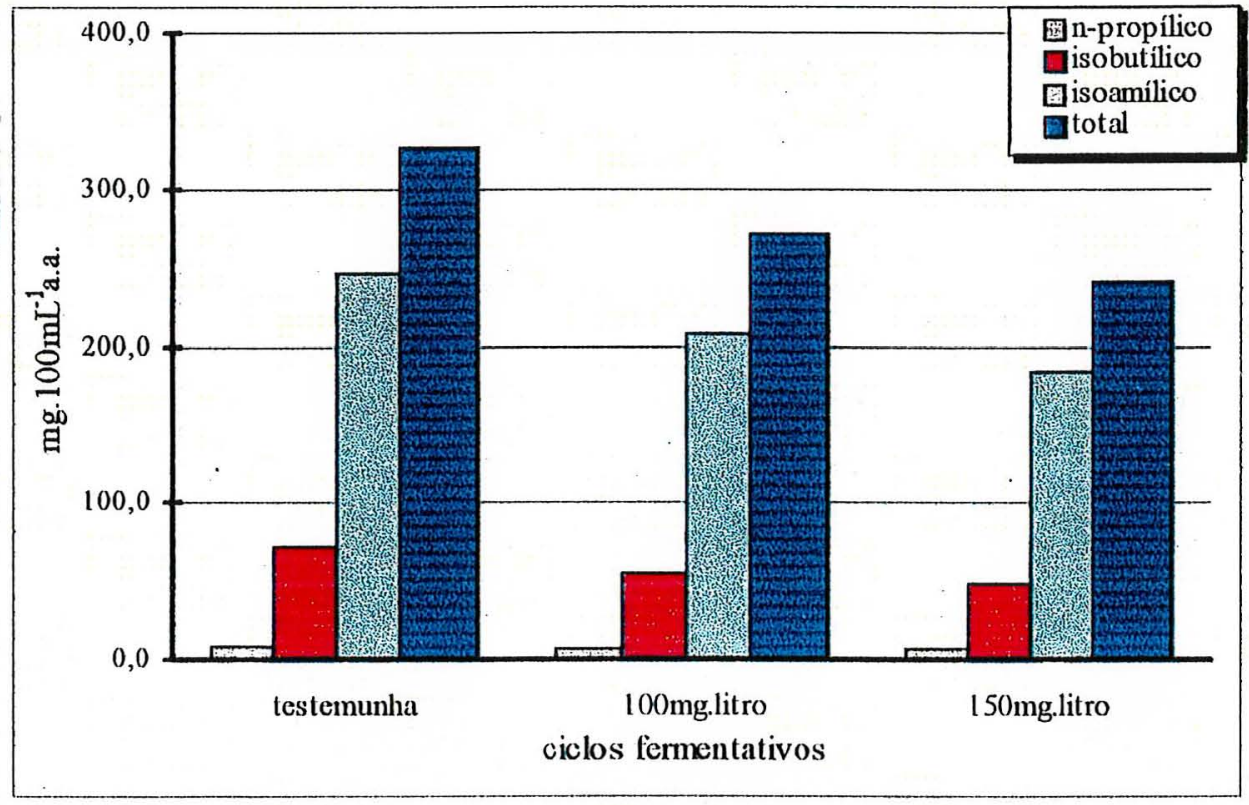

Figura 1.. Teores de álcoois superiores em aguardentes, em $\mathrm{mg} .100 \mathrm{~mL}^{-1}$ de álcool anidro, médias de duas repetições.

Os teores relatados por Ribeiro (1997), em aguardente de caldo de cana fermentado com a levedura FP são de $188,53 \mathrm{mg} \cdot 100 \mathrm{~mL}^{-1}$ de álcool anidro em aguardente com 40,03\% de álcool; $265,70 \mathrm{mg} \cdot 100 \mathrm{~mL}^{-1}$ de álcool anidro para a aguardente com 39,97\% de álcool obtida pela fermentação com a levedura LF e $376,08 \mathrm{mg} \cdot 100 \mathrm{~mL}^{-1}$ de álcool anidro para a aguardente com $40,03 \%$ de álcool obtida pela fermentação com a levedura IZ-987.

\subsection{Análise sensorial das aguardentes}

Para a realização das análises sensoriais foram selecionadas as duas aguardentes referentes ao tratamento testemunha e ao tratamento com $150 \mathrm{mg}^{\mathrm{L}} \mathrm{L}^{-1}$, pois 
as duas apresentaram as maiores diferenças nas concentrações de álcoois superiores.

$O$ teste de preferência foi realizado por uma equipe composta de 68 provadores não selecionados e não treinados, e avaliou dois atributos: sabor e aroma. Os resultados obtidos demonstram que não foi possível determinar a preferência entre as duas aguardentes em nenhum dos dois atributos analisados.

Na Tabela 19 são apresentados os valores obtidos na análise sensorial do atributo sabor das duas amostras de bebida. Ambas as aguardentes tiveram a mesma média final, 5,97; esse valor está localizado entre os parâmetros "indiferente" e "gostei ligeiramente", na escala hedônica de nove pontos.

Tabela 19. Análise sensorial de sabor de aguardentes, realizada por equipe não selecionada de provadores, com escala hedônica de nove pontos.

\begin{tabular}{cccccc}
\hline tratamento & $\begin{array}{c}\text { nota } \\
\text { máxima }\end{array}$ & $\begin{array}{c}\text { média } \\
\text { final }\end{array}$ & $\begin{array}{c}\text { nota } \\
\text { mínima }\end{array}$ & $\begin{array}{c}\text { desvio } \\
\text { padrão }\end{array}$ & pearson \\
\hline testemunha & 8,50 & 5,97 & 5,57 & 1,13 & 18,93 \\
150mg.L ${ }^{-1}$ & 9,00 & 5,97 & 5,35 & 1,78 & 29,82 \\
\hline
\end{tabular}

Com relação ao atributo aroma (Tabela 20), pode-se perceber uma maior aceitação que reflete apenas uma tendência de melhoria ao tratamento com $150 \mathrm{mg}$. $\mathrm{L}^{-1}$ do sal, que recebeu a nota média 6,0, pois o tratamento testemunha recebeu a nota média 5,87. Entretanto, as notas recebidas pelas duas amostras estão muito próximas uma da outra e não permitem estabelecer diferenças estatísticas entre as amostras. Os valores também correspondem aos parâmetros "indiferente" e "gostei ligeiramente", na escala hedônica de nove pontos.

Tabela 20. Análise sensorial de aroma de aguardentes, realizada por equipe não selecionada de provadores, com escala hedônica de nove pontos.

\begin{tabular}{cccccc}
\hline tratamento & $\begin{array}{c}\text { nota } \\
\text { máxima }\end{array}$ & $\begin{array}{c}\text { média } \\
\text { final }\end{array}$ & $\begin{array}{c}\text { nota } \\
\text { mínima }\end{array}$ & $\begin{array}{c}\text { desvio } \\
\text { padrão }\end{array}$ & pearson \\
\hline testemunha & 8,00 & 5,87 & 3,50 & 1,10 & 18,74 \\
150mg.L-1 & 8,50 & 6,00 & 3,00 & 1,30 & 21,67 \\
\hline
\end{tabular}


No teste triangular realizado por uma equipe de oito provadores selecionados, para verificar diferenças entre as bebidas, não foram detectadas diferenças significativas nos atributos de aroma e sabor, indicando que o uso do benzoato de sódio não exerce influência nas características sensoriais da aguardente. Segundo Dutcosky (1996) seriam necessárias, no mínimo, seis respostas corretas para detectar diferenças entre as duas bebidas.

Tabela 21. Resultados da análise sensorial, teste triangular, das aguardentes realizada por equipe selecionada de provadores.

\begin{tabular}{lcc}
\hline \multicolumn{1}{c}{ julgamentos } & sabor & aroma \\
\hline número de julgamentos & 8 & 8 \\
julgamentos corretos & 5 & 3 \\
julgamentos errados & 3 & 5 \\
\hline
\end{tabular}

A não detecção de diferenças sensoriais entre as aguardentes testadas é um resultado extremamente interessante porque demostrou que a redução dos álcoois superiores não interferiu na qualidade organoléptica do produto final. Apesar da similaridade dos resultados da análise sensorial, é relevante lembrar que as características organoléticas de aguardentes são o resultado da combinação de muitos componentes e, tanto o sabor quanto o aroma são uma combinação qualitativa e quantitativa de muitos elementos e não apenas de álcoois superiores.

\subsection{Considerações}

Os resultados obtidos na redução de álcoois superiores pela adição de benzoato de sódio sugerem a possibilidade do uso de benzoato de sódio na produção de aguardentes, entretanto, é necessária a continuidade de pesquisas com a utilização do sal, principalmente a utilização de outras linhagens de leveduras, a adição do sal de modo alternado e a associação com outras práticas, como o tratamento do mosto com 
ácido sulfúrico, que possibilitem reduzir a viabilidade das bactérias presentes. Outro parâmetro que deve ser monitorado é o desenvolvimento de bactérias.

Baseado nos resultados obtidos não é possivel recomendar o uso do benzoato de sódio para a redução de álcoois superiores, durante a fermentação alcoólica. Para isto é necessário a realização de mais estudos. 


\section{CONCLUSÕES}

Em relação aos parâmetros avaliados, a adição de 100 e $150 \mathrm{mg}^{-L^{-1}}$ de benzoato de sódio na fermentação de caldo de cana prejudicou o processo fermentativo causando redução significativa do teor alcoólico, da viabilidade celular, do consumo de açúcares, além de promover aumento significativo no teor de acidez total e volátil e no tempo de fermentação; entretanto, favoreceu a redução significativa na formação dos álcoois isoamílico e isobutílico tornando evidente o potencial representado pelo inibidor.

Os resultados obtidos nas análises sensoriais de preferência e de diferença demonstram que o uso do benzoato de sódio não alterou a qualidade organoléptica das aguardentes com relação aos atributos de aroma e sabor. 


\section{REFERÊNCIAS BIBLIOGRÁFICAS}

ALMEIDA, M.E.W.; BARRETO, H.H.C. Determinação de álcoois superiores em aguardente de frutas por cromatografia em fase gasosa. Revista Instituto Adolfo Lutz, v.33, p. 73-84. 1973.

ALMEIDA, P.G. Conservação química dos refrigerantes. O Engarrafador Moderno, v.5, n.38, p. 60-65. mar/abr. 1995.

ALMEIDA, P.G. O uso de acidulantes e conservantes em bebidas. O Engarrafador Moderno, v.7, n.47, p.41-48. set/out. 1996.

ALVES, D.M.G. Fatores que afetam a formação de ácidos orgânicos bem como outros parâmetros da fermentação alcoólica. Piracicaba, 1994. 274p. Dissertação (Mestrado) - Escola Superior de Agricultura "Luiz de Queiroz", Universidade de São Paulo.

AMERINE, M.A.; OUGH, C.S. Wine and must analysis. London: John Wiley \& Sons, 1974. 121p.

AYRAPAA, T. Effect of temperature on the formation of higher alcohols by culture yeasts. In: Chemical Abstracts, n.73: p. 2653. 1970.

AYRAPAA, T. Formation of higher alcohols from amino acids derived from yeast proteins. Journal of the Institute of Brewing, v.73, p. 30-33. 1967.

BACILA, M. Curso de fisiologia de microrganismos. Curitiba: Instituto de bioquímica, Universidade Federal do Paraná. 1960. 209p

BARONE, M.C. Influência da condução do processo de fermentação sobre a qualidade e 
produtividade do hidromel. Piracicaba, 1994. Dissertação (Mestrado) - Escola Superior de Agricultura "Luiz de Queiroz", Universidade de São Paulo.

BOZA, Y.E.A.G. Influência da condução da destilação sobre a composição e a qualidade sensorial da aguardente de cana. Piracicaba, 1996. 143p. Dissertação (Mestrado) - Escola Superior de Agricultura "Luiz de Queiroz", Universidade de São Paulo.

BRASIL, Ministério da Agricultura e Reforma Agrária. 1974. Portaria n.o 371, Diário Oficial da União, 09 de set. 1974. Seção I, Parte I, Suplemento, 19/09/1974. p. 53-62.

CHAVES, J.B.P.; PÓVOA, M.E.B. A Qualidade da aguardente de cana-de-açúcar. In: MUTTON, M.J.R.; MUTTON, M.A. Aguardente de cana - produção e qualidade. Jaboticabal: FUNEP, 1992. p.93-132.

CHERUBIN, R. A.; ROSAS, A. S.; WOSIACKI, G. Influência da presença de metabissulfito de sódio sobre os teores de acetaldeído no destilado. IV ENCONTRO ANUAL DE INICIAÇÃO CIENTÍFICA. Maringá, 1995. p.529. Anais

CHICHESTER, D.F.; TANNER JÚNIOR, F.W. Antimicrobial food additives. In: FURIA, T.E. Handbook of food additives, Boca Raton, CRC Press Inc. 1985.

COELHO, R..S. O que penso da cachaça. Copo Liso, Ano I, n. 0. Dez/jan, 1990

COPERSUCAR. Fermentação. Cooperativa dos Produtores de Cana, Açúcar e Álcool do Estado de São Paulo. Centro de Tecnologia Coopersucar. Divisão Industrial. 1987. 434p.

DUTCOSKY, S.D. Análise Sensorial de Alimentos. Curitiba: Ed. Champagnat, 1996. 123p.

FAHRASMANE, L.; PARFAIT, A.; JOURET, C.; GALZY, P. Etude de l'acideté volatile des rhums des Antilles Françaises. Industries Alimentares et Agricoles. v.100, n.5, p297-301. 1983. 
FALCONE, M. \& MARQUES, A.B.; Estudos sobre as condições de hidrólise pelo ácido clorídrico na dosagem de açúcares redutores totais. Tecnologia de Alimentos e Bebidas, v.4, p.24-29.

FURTADO, S.M.B. Avaliação sensorial descritiva de aguardente de cana (Saccharum officinarum L.). Influência da composição em suas características sensoriais e correlação entre as medidas sensoriais e físico-químicas. Campinas, 1995. 99p. Tese (Doutorado) - Faculdade de Engenharia de Alimentos, Universidade Estadual de Campinas.

GAO, C.; FLEET, G.H. The effects of temperature and $\mathrm{pH}$ on the ethanol tolerance of the wine yeasts, Saccharomyces cerevisiae, Candida Stellata and Kloeckera apiculata. Journal Applied Bacteriology, n.65, p. 405-409. 1988.

GOMES, F.P. Curso de estatística experimental. 13. ed. Piracicaba: Nobel, 1990. Cap. 3, p.18-41.

GUTIERREZ, L.E. Bioquímica de leveduras. Piracicaba, 1997. Escola Superior de Agricultura "Luiz de Queiroz"/Universidade de São Paulo.

GUTIERREZ, L.E. Efeito da adição de sulfito sobre a produção álcoois superiores durante a fermentação alcoólica. Anais da Escola Superior de Agricultura "Luiz de Queiroz", v.48, n.2, p. 359-368, 1988a

GUTIERREZ, L.E. Efeito da adição de ácidos fórmico e propiônico sobre a produção de álcoois superiores durante a fermentação alcoólica. Anais da Escola Superior de Agricultura "Luiz de Queiroz", v.45, n.2, p. 369-379, 1988 b.

GUTIERREZ, L.E. Estudo Comparativo da fermentação alcoólica por linhagens de Saccharomyces cerevisiae e Saccharomyces uvarum. Piracicaba, 1994. Tese (Livre docência) - Escola Superior de Agricultura "Luiz de Queiroz", Universidade de São Paulo.

GUTIERREZ, L.E. Inibidores da fermentação alcoólica. Stab, Açúcar, Álcool e Subprodutos. V.9, n.6, p. 24-30. Jul/ago. 1991. 
GUTIERREZ, L.E. Produção de álcoois superiores por linhagens Saccharomyces cerevisine durante a fermentação alcoólica. Scientia Agrícola, v.50, n.3, p. 464-472, 1992

GUTIERREZ, L.E. Tópicos de bioquímica de leveduras. Piracicaba, 1989. Escola Superior de Agricultura "Luiz de Queiroz", Universidade de São Paulo.

GUTIERREZ, L.E.; ANNICCHNO, A.V.K.O.; LUCATTI, L. Capacidade fermentativa de Saccharomyces cerevisiae enriquecida com ácidos graxos. Anais da Escola Superior de Agricultura "Luiz de Queiroz", v.47, n.2, p. 575-595, 1990.

GUTIERREZ, L.E.; ANNICCHINO, A.V.K.O.; LUCATTI, L.; STIPP, J.M.S.; SILVA, S.B.L. Aumento da produção de etanol a partir de melaço de cana-de-açúcar pela adição de benzoato. Anais da Escola Superior de Agricultura "Luiz de Queiroz", n.48, p. 1-21, 1991.

GUTIERREZ, L.E.; DE MARTIN, V.F. Efeito do nitrito sobre a fermentação alcoólica realizada por Saccharomyces cerevisiae. Anais da Escola Superior de Agricultura "Luiz de Queiroz", n.48, p. 41-44, 1991.

HOUGH, J.S.; STEVENS, R. Beer flavour. IV. Factors affecting the production of fusel oil. Journal of the Institute of Brewing, n.67, p. 488-494. 1961.

INSTITUTO ADOLFO LUTZ. Normas analíticas do Instituto Adolfo Lutz: volume 1 - Métodos químicos e físicos para a análise de alimentos. 3a ed. São Paulo: 1985, 533p.

LEHNINGER, A.L. Principios de bioquímica. São Paulo: Ed. Savier, 1990. 725p.

LIMA, U.A. Aguardentes. In: AQUARONE, E; LIMA, U.A.; BORZANI, W. Alimentos e bebidas produzidos por fermentação. São Paulo: Edgard Blucher, 1983. p. 79-103. (Biotecnologia, 5)

LIMA, U.A. Produção nacional de aguardentes e potencialidade dos mercados internos e externos In: MUTTON, M.J.R.; MUTTON, M.A. Aguardente de cana - produção e qualidade. 
Jaboticabal: FUNEP, 1992. p. 151-163.

MORI, E.E.M. Métodos sensoriais e físicos para a avaliação de alimentos e bebidas: princípios e aplicação. Campinas: ITAL, 1992.

NASCIMENTO, R.F.; LIMA NETO, B.S.; FRANCO. D.W. Aldeídos em bebidas alcoólicas fermento-destiladas. O Engarrafador Moderno, v.7, n.49, p. 75-77. jan/fev. 1997.

NYKANEN, L.; NYKANEN, I. Distilled Beverages. In: MAARSE, H. ed. Volatile conpounds in foods and beverages. New York: Marcell Dekker Inc., 1991. Cap 15.

NORDSTROM, K. Formation of esters, acids and alcohols from alphaketo acids by brewers yeast. Journal of the Institute of Brewing, v.69, p. 483-495. 1963.

NORMAN, W.D. The technology of food preservation. 3o ed., New Jersey: Mack Printing Company, 1970.493p.

NOVAES, F.V. Em nome da qualidade da aguardente de cana. O Engarrafador Moderno, v.7, n.46, p. 68-73, jan/fev. 1997.

NOVAES, F.V. Testes e análises realizados para assegurar a qualidade da aguardente brasileira. O Engarrafador Moderno, v.7, n.46, p. 79-81, jul./ago. 1996.

NOVAES, F.V.; STUPIELLO, J.P.; OLIVEIRA, E.R.; VALSECHI, O. I Curso de extensão em tecnologia de aguardentes de cana - apontamentos. Piracicaba: ESALQ./Departamento de Ciência e Tecnologia Agro-industrial, 1974. 104p.

OKOLO, B.; JOHNSTON, J.R.; BERRY, D.R. Toxicity of ethanol, n-butanol and iso-amyl alcohol in Sacchnromyces cerevisine when supplied separately and in mixtures. Biotechnology Letters, v.9, v.6, p. 431-434. 1987.

QUAIN, D.E. Studies on yeast physiology-impact on fermentation performance and product 
quality. Jornal of the Institute of Brewing, v.95, p315-323, 1988.

RANKINE, B.C. Formation of higher alcohols by wine yeasts and relationship to taste thresholds. Journal Science Food Agriculture, v.18, p. 583-589. 1967.

RIBEIRO, C.A.F. Potencialidades de diferentes linhagens de levedura da espécie Saccharomyces cerevisiae na tecnologia de aguardente de cana. Piracicaba, 1997. 107p. Dissertação (Mestrado) - Escola Superior de Agricultura "Luiz de Queiroz", Universidade de São Paulo.

ROSAS, A. S.; CHERUBIN, R.A.; WOSIACKI. Evolução de componentes secundários durante o processo de destilação de vinho de laranja. IV ENCONTRO ANUAL DE INICIAÇÃO CIENTÍFICA. Maringá, 1995.p.528. Anais.

SAIGAL, D.; VISWANATHAN, L. Effect of oils and fatty acids on the tolerance of distiller s yeast to alcohol and temperatures. International Sugar Journal, v.85, n. 1017, p. 266-269. 1983.

SAKAI, L.A.; GONÇALVES, R.H; HORII, J. Matéria seca em leveduras. Comparação entre secagem em estufa e em forno de microondas. In Congresso de iniciação científica da ESALQ, 5. Piracicaba, ESALQ, 1990. p 74.

SIMÃO, A.M. Aditivos para alimentos sob o aspecto toxicológico. São Paulo: Nobel. 1985. 274p.

STUPIELLO, J.P. Destilação do vinho. In: MUTTON, M.J.R.; MUTTON, M.A. Aguardente de cana - Produção e qualidade. Jaboticabal: FUNEP, 1992. p. 67-78.

SUOMALAINEN, $\mathrm{H}$. Yeast and its effect on the flavour of alcoholic beverages. Journal of the Institute of Brewing, v.77, p. 164-177. 1971.

SUOMALAINEN, $\mathrm{H}$; LEHTONEN, $M$. The production of aroma compounds by yeast. Journal of the Institute of Brewing, v.85, n.3, p.149-56, 1978.

SUOMALAINEN, H.; KAHANPAA, H. Formation of fusel alcohols from amino acids with 
branched chains. Journal of the Institute of Brewing, v.69, p. 473-478. 1963.

SUOMALAINEN, H.; KERANEN, A.J.A. Keto acids formed by baker s yeast. Journal of the Institute of Brewing, v.73, p. 477-483. 1967b.

SUOMALAINEN, H.; KERANEN, A.J.A. Valine, leucine and isoleucine as precursors of branched fatty acids in yeast. Suomen Kemistilehti, v.40, p. 288-289. 1967a.

SUOMALAINEN, H.; NYKANEN, L. The aroma components produced by yeast in nitrogen-free sugar solution. Journal of the Institute of Brewing, v.72, p. 469-474. 1966.

SUOMALAINEN, H.; OURA, E. Cell permeability and descarboxylation of alpha-keto acids by intact yeast. Biochimistry Biophysical. Acta, v.28, p. 120-127. 1958.

SUOMALAINEN, H.; OURA, E. Yeast carboxylase and cell permeability. Acta Chemica Scandinavica, v.11, n.6, p. 1090. 1957.

WALSH, R.M.; MARTIN, P.A. Growth of Saccharomyces cerevisiae and Saccharomyces uvarum in a temperature gradient incubator. Journal of the Institute of Brewing, v.83, p. 169-172. 1977.

WEBB, A.D.; INGRAHAM, J.L. Fusel oil. Advances Applied Microbiology, v.5, p. 317-353. 1963.

WEBB, A.D.; KEPNER, R.E. Fusel oil analysis by means of gas-liquid partition chromatography. American Journal Enology Viticulture, v.12, p. 51-59. 1961.

YOSHIZAWA, K.; FURUKAWA, T.; TADENUMA, M.; YAMADA, M. The formation of higher alcohols in the fermentation of amino acids by yeast. The determination of alcohols with gas chromatography. Agricultural Biological Chemistry, v.5, n.4, p. 326-332. 1961. 
APÊNDICES 


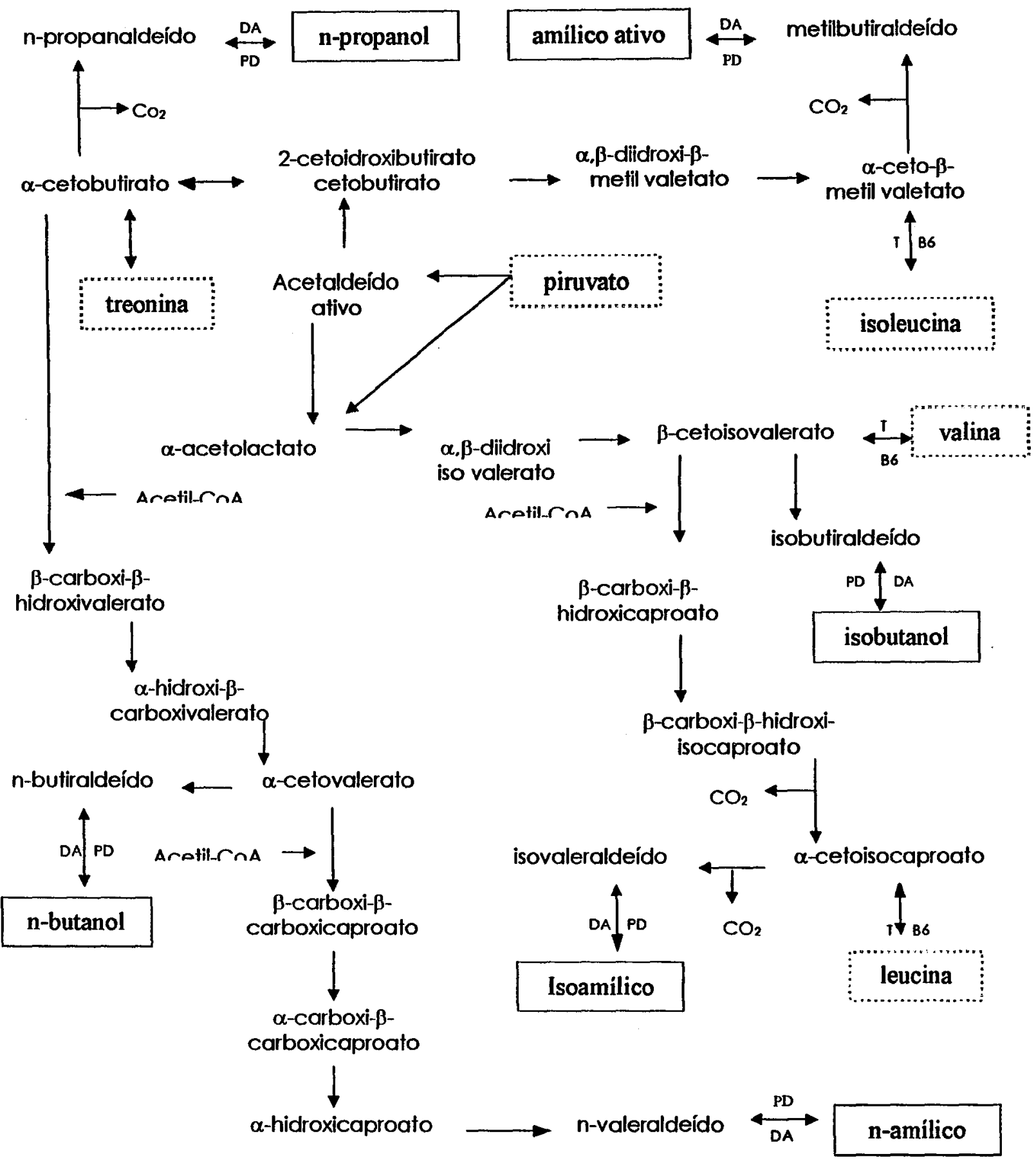

(PD = piruvato descarboxilase; $\mathbf{T}=$ transaminase $; \mathbf{D A}=$ desidrogenase alcoólica; $\mathbf{B 6}=$ piridoxal fosfato)

Apêndice 1. Vias biossintéticas de formação de álcoois superiores (Webb \& Ingraham, 1963). 
Julgador:

data:

\section{TESTE TRIANGULAR}

Em cada grupo de amostras apresentadas, duas são iguais e uma é diferente. Deguste cuidadosamente cada uma das amostras, na ordem em que estão sendo apresentadas, e faça um círculo em volta da amostra diferente.

\begin{tabular}{|c|ccc|}
\hline atributo & \multicolumn{3}{|c|}{ Códigos das amostras } \\
\hline sabor & 956 & 842 & 914 \\
\hline
\end{tabular}

Comentários:

Apêndice 2. Modelo de ficha utilizado para a análise sensorial (teste triangular) de aguardente (Dutcosky, 1996). 
Julgador:

data:

\section{ESCALA HEDÔNICA}

Deguste cuidadosamente a amostra e indique por números, através da escala apresentada abaixo, o quanto você gostou ou desgostou dos atributos, aroma e sabor, da amostra em teste:

1 - Desgostei extremamente

2 - Desgostei muito

3 - Desgostei moderadamente

4 - Desgostei ligeiramente

5 - Indiferente

6 - Gostei ligeiramente

7 - Gostei moderadamente

8 - Gostei muito

9 - Gostei extremamente

\begin{tabular}{|c|c|}
\hline atributo & nota \\
\hline Aroma & \\
\hline Sabor & \\
\hline
\end{tabular}

Comentários:

Apêndice 3. Modelo de ficha utilizado para a análise sensorial (teste triangular) de aguardente (Dutcosky, 1996). 


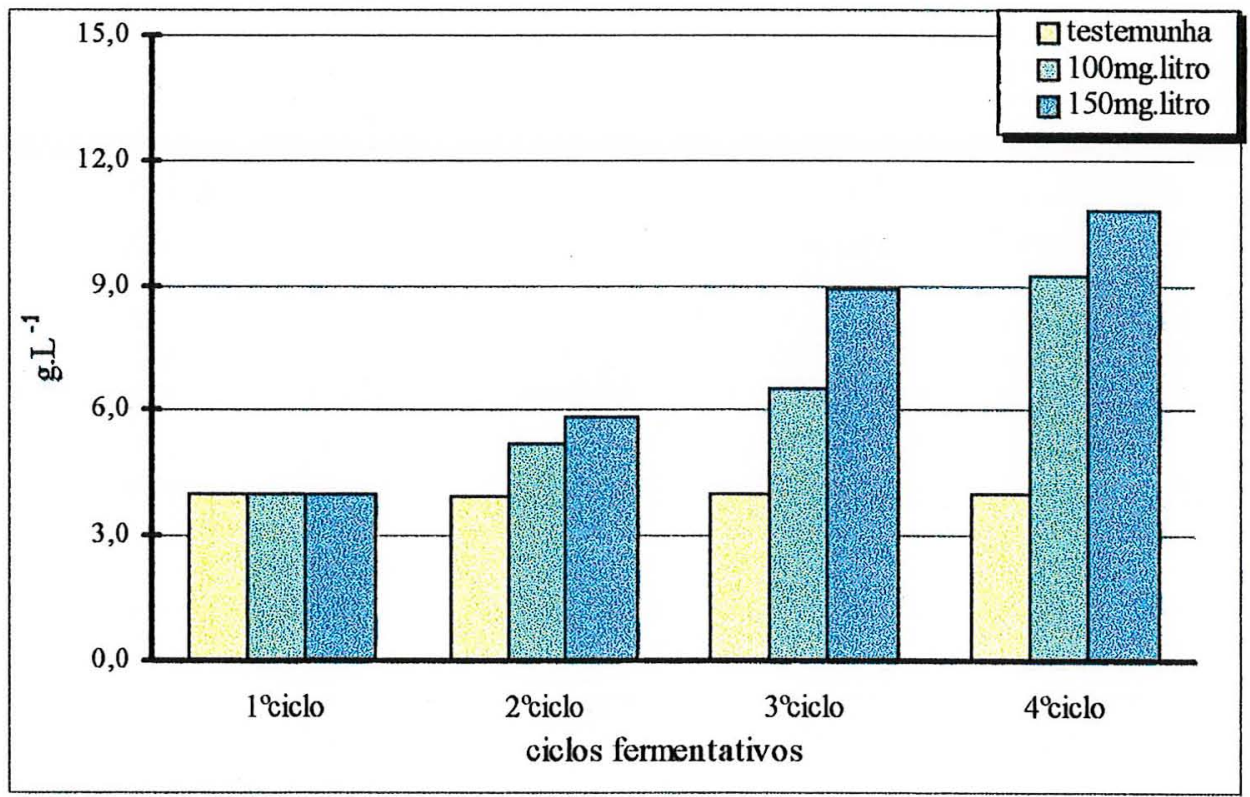

Apêndice 4. Teores de ácidos orgânicos nos vinhos, em g. $\mathrm{L}^{-1}$, expressos em ácido acético, médias de quatro repetições.

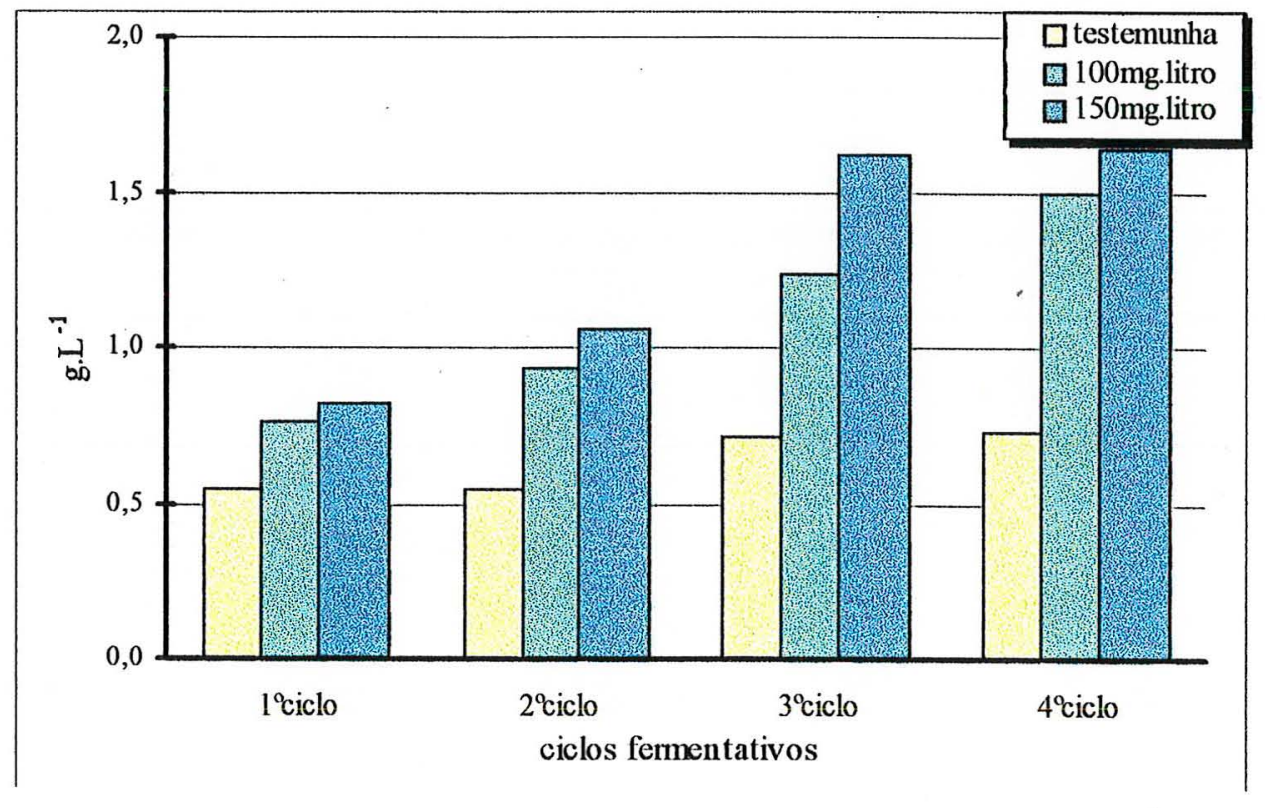

Apêndice 5. Teores de ácidos voláteis nos vinhos, em g. $\mathrm{L}^{-1}$, expressos em ácido acético, médias de quatro repetições. 


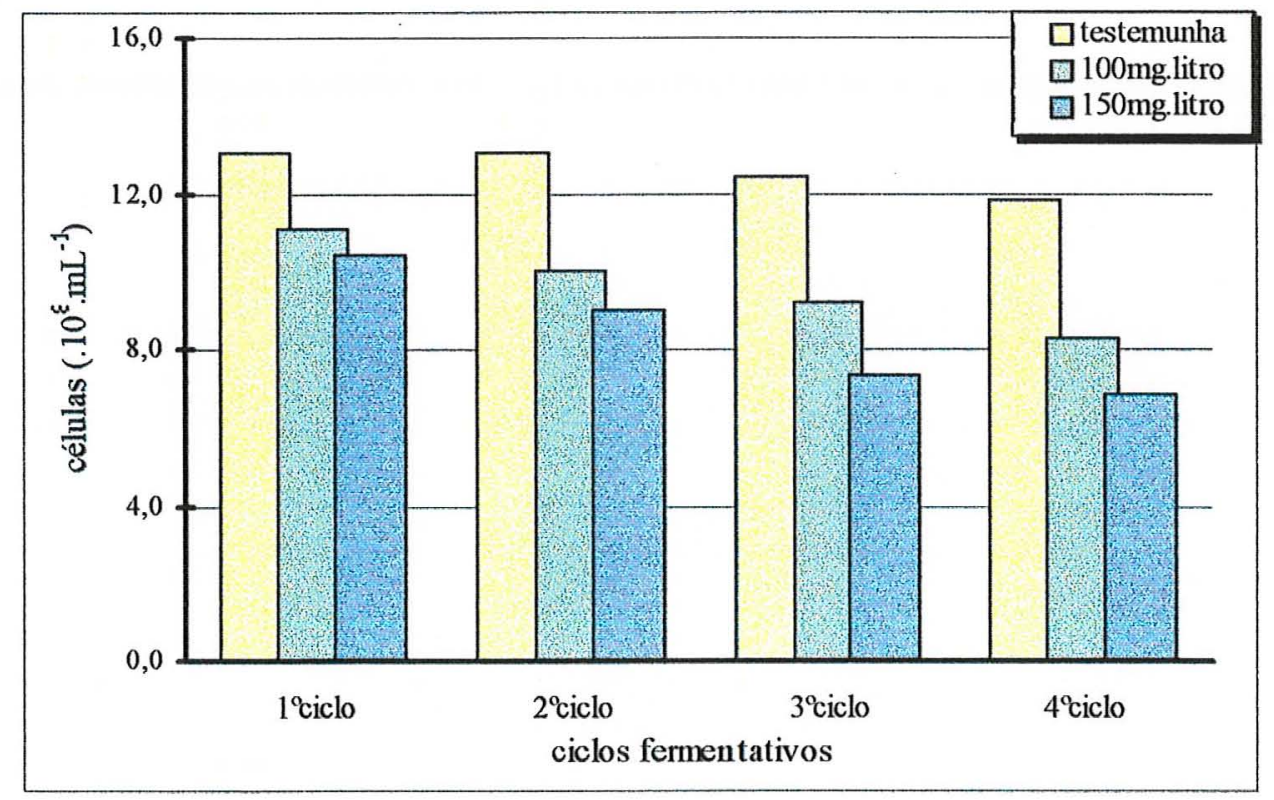

Apêndice 6. Número total de células (células. $\mathrm{mL}^{-1}$ ) e viabilidade celular (\%) das leveduras após as fermentaç̃os, médias de quatro repetições.

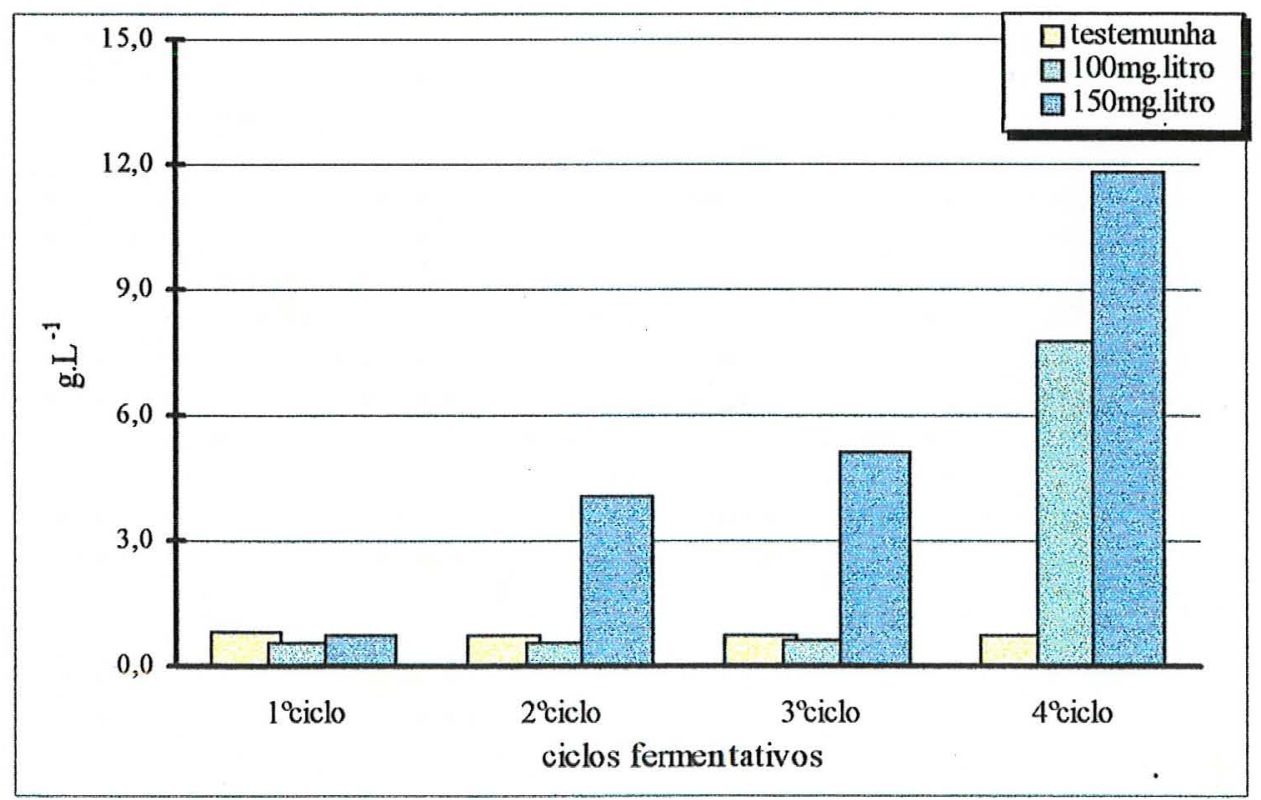

Apêndice 7. Teores de açúcares residuais nos vinhos, em g.L $\mathrm{L}^{-1}$ expressos em glucose, médias de quatro repetições. 


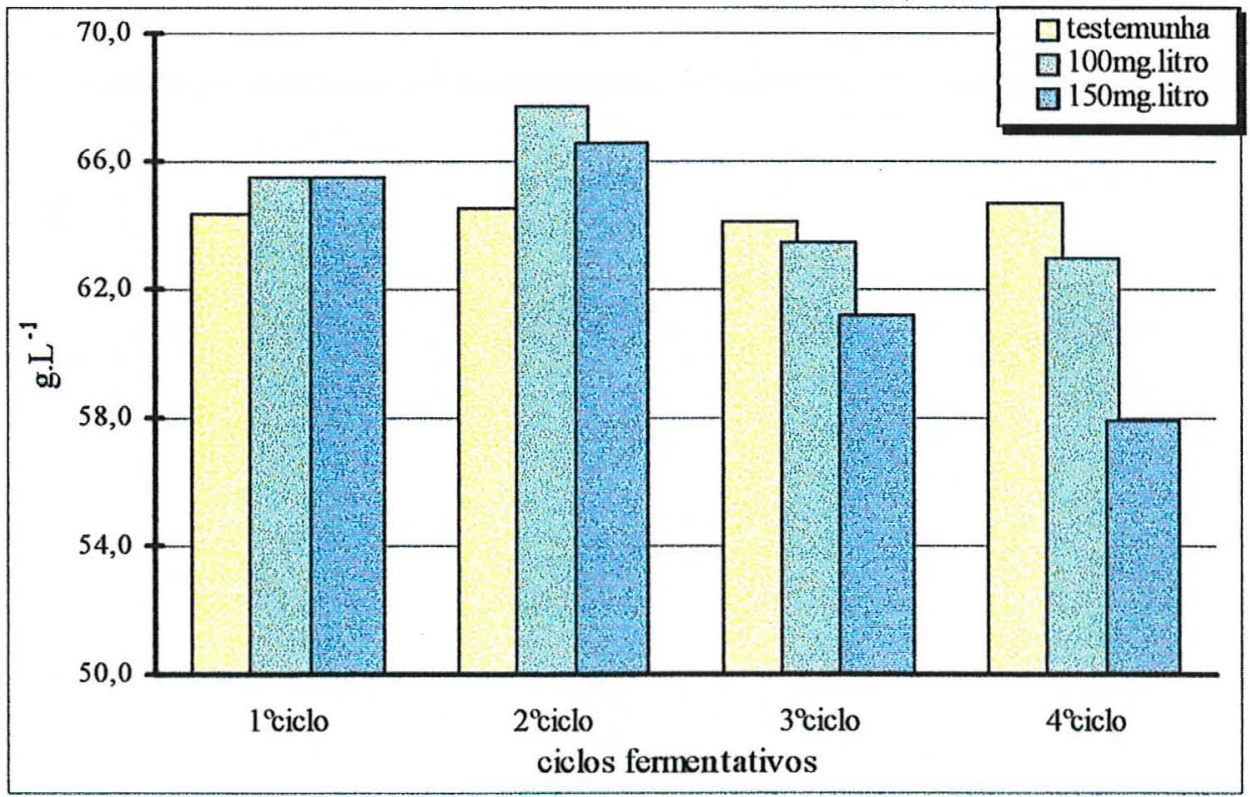

Apêndice 8. Teor alcoólico dos vinhos, em g. $\mathrm{L}^{-1}$, médias de quatro repetições.

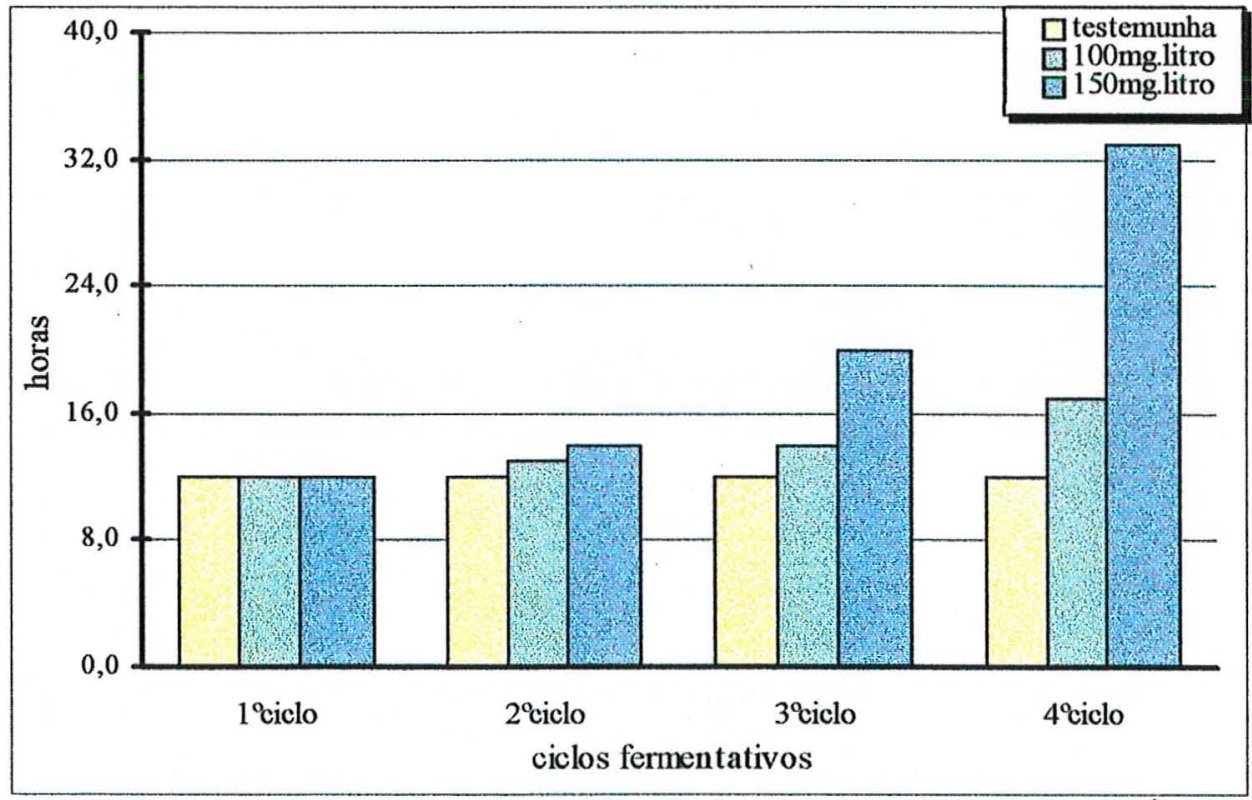

Apêndice 10. Efeito da adição de benzoato de sódio no tempo de fermentação, em horas, médias de quatro repetições. 


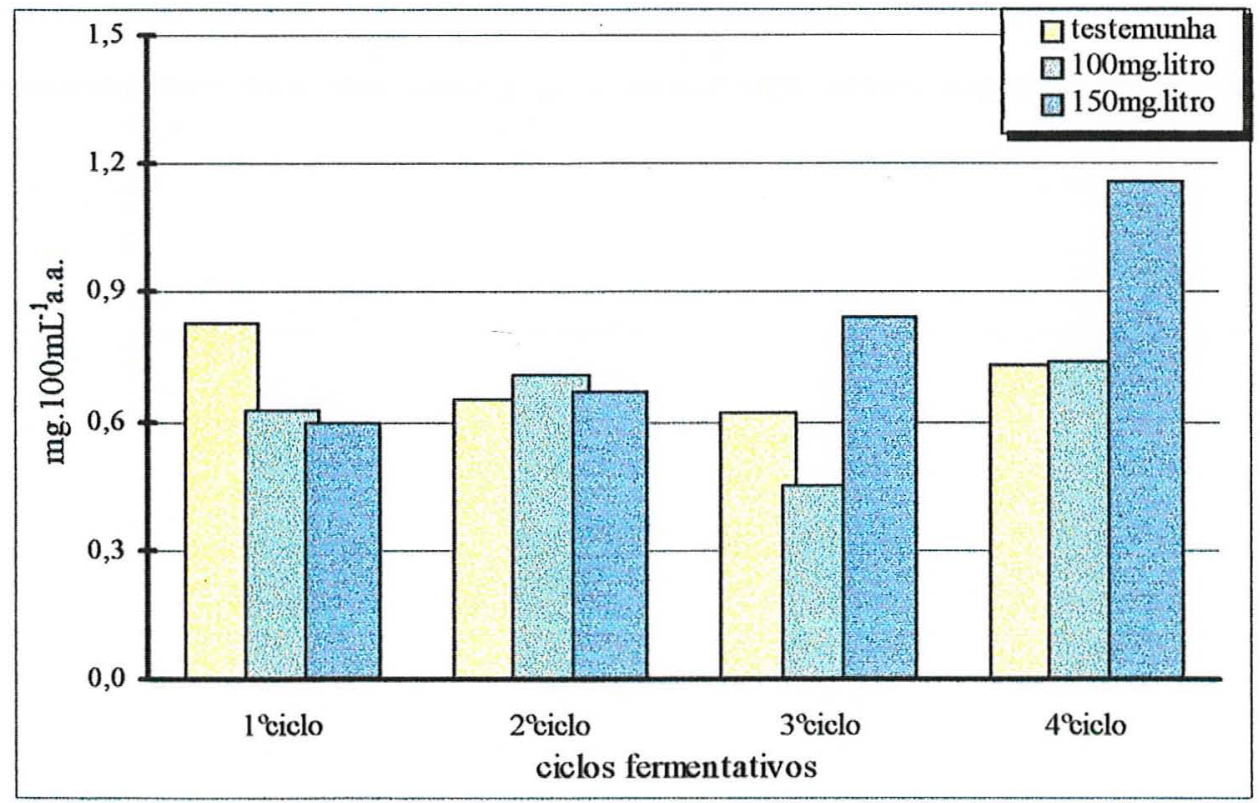

Apêndice 11. Teores de álcool n-propílico nos vinhos, em mg.100 $\mathrm{mL}^{-1}$, médias de quatro repetições.

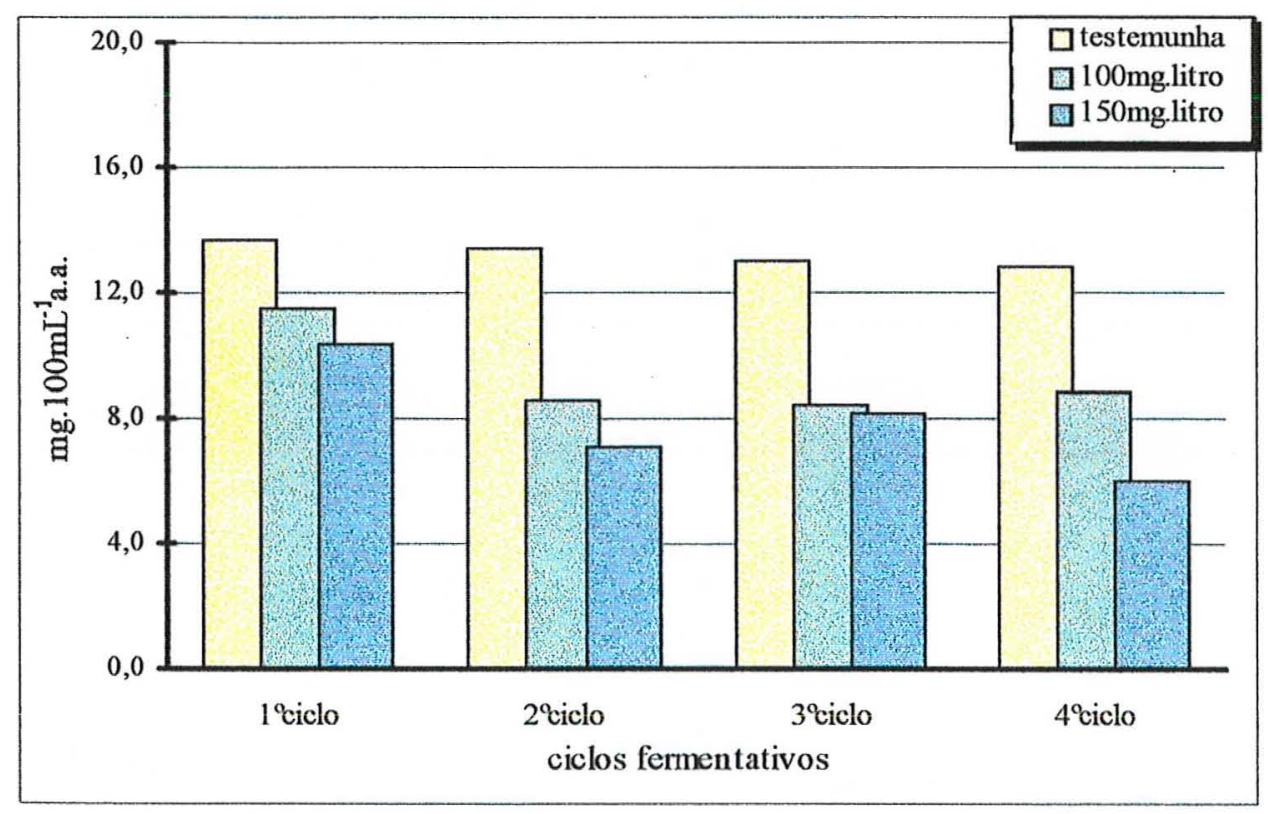

Apêndice 12. Teores de álcool isoamílico nos vinhos, em mg. $100 \mathrm{~mL}^{-1}$, médias de quatro repetições. 


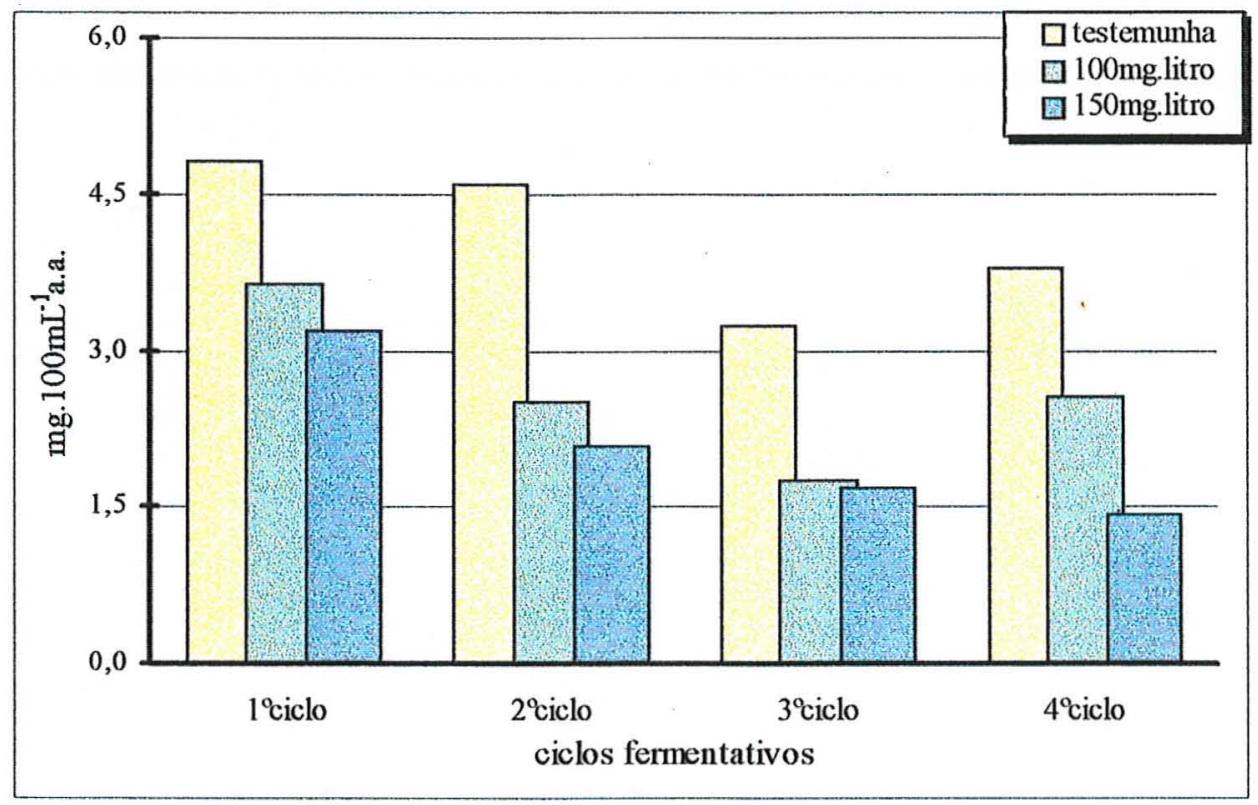

Apêndice 13. Teores de álcool isobutílico nos vinhos, em $\mathrm{mg} \cdot 100 \mathrm{~mL}^{-1}$, médias de quatro repetições. 